\title{
Two Players Make a Formidable Combination: In Situ Generated Poly(acrylic anhydride-2-methyl-acrylic acid-2-oxirane-ethyl ester- methyl methacrylate) Cross-Linking Gel Polymer Electrolyte toward 5 V High-Voltage Batteries
}

\author{
Yue Ma, ${ }^{\dagger, \|}$ Jun Ma, Jingchao Chai, ${ }^{\dagger}, \|$ Zhihong Liu, ${ }^{\dagger}$ Guoliang Ding, ${ }^{\dagger}$ Gaojie $\mathrm{Xu},{ }^{\dagger}$ Haisheng Liu, ${ }^{\dagger}$ \\ Bingbing Chen, ${ }^{\dagger}$ Xinhong Zhou, ${ }^{\dagger}$ Guanglei Cui, $*{ }^{\dagger} \dagger \odot$ and Liquan Chen ${ }^{\dagger, \S}$
}

${ }^{\dagger}$ Qingdao Industrial Energy Storage Research Institute, Qingdao Institute of Bioenergy and Bioprocess Technology, Chinese Academy of Sciences, Qingdao 266101, P. R. China

"University of Chinese Academy of Sciences, Beijing 100049, P. R. China

${ }^{\ddagger}$ College of Chemistry and Molecular Engineering, Qingdao University of Science \& Technology, Qingdao 266042, P. R. China

${ }^{\S}$ Key Laboratory for Renewable Energy, Beijing Key Laboratory for New Energy Materials and Devices, Beijing National Laboratory for Condensed Matter Physics, Institute of Physics, Chinese Academy of Sciences, Beijing 100190, P. R. China

\section{Supporting Information}

\begin{abstract}
Electrochemical performance of high-voltage lithium batteries with high energy density is limited because of the electrolyte instability and the electrode/electrolyte interfacial reactivity. Hence, a cross-linking polymer network of poly(acrylic anhydride-2methyl-acrylic acid-2-oxirane-ethyl ester-methyl methacrylate) (PAMM)-based electrolyte was introduced via in situ polymerization inspired by "shuangjian hebi", which is a statement in a traditional Chinese Kungfu story similar to the synergetic effect of $1+1>$ 2. A poly(acrylic anhydride) and poly(methyl methacrylate)-based system is very promising as electrolyte materials for lithium-ion batteries, in which the anhydride and acrylate groups can provide high voltage resistance and fast ionic conductivity, respectively. As a result, the cross-linking PAMM-based electrolyte possesses a significant comprehensive enhancement, including electrochemical stability window exceeding $5 \mathrm{~V}$ vs $\mathrm{Li}^{+} / \mathrm{Li}$, an ionic conductivity of $6.79 \times 10^{-4} \mathrm{~S} \mathrm{~cm}^{-1}$ at room temperature, high mechanical strength $(27.5 \mathrm{MPa})$, good flame resistance, and excellent interface compatibility with $\mathrm{Li}$ metal. It is also demonstrated that this gel polymer electrolyte suppresses the negative effect resulting from dissolution of $\mathrm{Mn}^{2+}$ ions at 25 and $55^{\circ} \mathrm{C}$. Thus, the $\mathrm{LiNi}_{0.5} \mathrm{Mn}_{1.5} \mathrm{O}_{4} / \mathrm{Li}$ and $\mathrm{LiNi}_{0.5} \mathrm{Mn}_{1.5} \mathrm{O}_{4} / \mathrm{Li}_{4} \mathrm{Ti}_{5} \mathrm{O}_{12}$ cells using the optimized in situ polymerized cross-linking PAMM-based gel polymer electrolyte deliver stable charging/discharging profiles and excellent rate performance at room temperature and even at $55{ }^{\circ} \mathrm{C}$. These findings suggest that the cross-linking PAMM is an intriguing candidate for $5 \mathrm{~V}$ class high-voltage gel polymer electrolyte toward high-energy lithium-on batteries.

KEYWORDS: poly(acrylic anhydride), poly(methyl methacrylate), in situ polymerization, gel polymer electrolyte, high voltage lithium batteries
\end{abstract}

\section{INTRODUCTION}

Recently, high-energy-density lithium-ion batteries (LIBs) have been extensively researched to mitigate the energy issues. ${ }^{1-3}$ Spinel $\mathrm{LiNi}_{0.5} \mathrm{Mn}_{1.5} \mathrm{O}_{4}$, having high working voltage plateau $\left(\sim 4.7 \mathrm{~V} \mathrm{vs} \mathrm{Li}^{+} / \mathrm{Li}\right)$ and theoretical capacity $\left(148 \mathrm{mAh} \mathrm{g}^{-1}\right)$, is a promising cathode material for high-energy-density LIBs. ${ }^{4-6}$ However, the conventional carbonate-based liquid electrolytes fail to meet the requirement of $\mathrm{LiNi}_{0.5} \mathrm{Mn}_{1.5} \mathrm{O}_{4}$ practical application because of the low breakdown voltage below 4.5 $\mathrm{V}$ vs $\mathrm{Li}^{+} / \mathrm{Li}^{7,8}$ Moreover, the interface reaction of $\mathrm{Mn}^{2+}$ ions dissolution from $\mathrm{LiNi}_{0.5} \mathrm{Mn}_{1.5} \mathrm{O}_{4}$ cathode deteriorates the battery cycling stability seriously. ${ }^{9-12}$ As a result, various efforts have been made to achieve excellent electrolyte system in the past few years. ${ }^{13-15}$ Our group has presented a series of cyanobased polymer electrolytes (Table 1 ) that display high voltage resistance $(\geq 4.7 \mathrm{~V})$, high ionic conductivity $\left(>1 \times 10^{-3} \mathrm{~S}\right.$ $\mathrm{cm}^{-1}$ ) at room temperature, and excellent safety. ${ }^{16,17}$ In addition, the strong chelation of cyano group to transition metal ions can effectively suppress the transfer of $\mathrm{Mn}^{2+}$ ions from $\mathrm{LiNi}_{0.5} \mathrm{Mn}_{1.5} \mathrm{O}_{4}$ to the opposite anode and then enhance the interface stability. Therefore, exploring novel versatile polymer electrolyte is significant to the application of $\mathrm{LiNi}_{0.5} \mathrm{Mn}_{1.5} \mathrm{O}_{4}$ in high-energy-density LIBs. ${ }^{14,15,18,19}$

Anhydrides such as 1-propylphosphonic acid cyclic anhydride $^{20}$ and glutaric anhydride ${ }^{21}$ are promising electrolyte additives for a high-voltage $\mathrm{LiNi}_{0.5} \mathrm{Mn}_{1.5} \mathrm{O}_{4}$ battery system. ${ }^{22,23}$

Received: July 31, 2017

Accepted: November 7, 2017

Published: November 7, 2017 
Table 1. Polymer Electrolytes for High-Voltage Lithium Batteries

\begin{tabular}{|c|c|c|c|c|c|c|}
\hline no. & polymer & cathode & $\begin{array}{l}\text { electrochemical stability }(\mathrm{V} \\
\text { vs } \mathrm{Li}+/ \mathrm{Li})\end{array}$ & $\begin{array}{c}\sigma\left(\mathrm{mS} \mathrm{cm}^{-1}\right) \text { at } \\
25{ }^{\circ} \mathrm{C}\end{array}$ & processing method & ref \\
\hline 1 & poly(methylethyl a-cyanoacrylate) & $\mathrm{LiNi}_{0.5} \mathrm{Mn}_{1.5} \mathrm{O}_{4}$ & 5.0 & 1.24 & electrospinning & 13 \\
\hline 2 & polyacrylonitrile/tri(ethylene glycol) diacrylate & $\mathrm{LiNi}_{0.6} \mathrm{Co}_{0.6} \mathrm{Mn}_{0.2} \mathrm{O}_{2}$ & & 10 & electrospinning & 14 \\
\hline 3 & $\begin{array}{l}\text { poly(methyl methacrylate-acrylonitrile-butyl } \\
\text { acrylate) }\end{array}$ & $\mathrm{LiNi}_{0.5} \mathrm{Mn}_{1.5} \mathrm{O}_{4}$ & 5.0 & 1.3 & electrospinning & 15 \\
\hline 4 & nitrile-based polymer electrolytes & $\begin{array}{l}\mathrm{LiCoO}_{2} / \\
\mathrm{LiNi}_{0.5} \mathrm{Mn}_{1.5} \mathrm{O}_{4}\end{array}$ & 4.7 & $>1$ & & 16 \\
\hline 5 & poly(ethyl $\alpha$-cyanoacrylate) nanocoating & $\mathrm{LiNi}_{0.5} \mathrm{Mn}_{1.5} \mathrm{O}_{4}$ & 4.7 & & $\begin{array}{l}\text { in- situ polymerization } \\
\text { method }\end{array}$ & 17 \\
\hline 6 & poly(propylene carbonate) & $\mathrm{LiNi}_{0.5} \mathrm{Mn}_{1.5} \mathrm{O}_{4}$ & 5.0 & 1.14 & solution-casting method & 18 \\
\hline 7 & $\begin{array}{l}\mathrm{P}(\text { methyl methacrylate-butyl acrylate- } \\
\text { acrylonitrile }) / \text { polyethylene })\end{array}$ & $\mathrm{LiNi}_{0.5} \mathrm{Mn}_{1.5} \mathrm{O}_{4}$ & 5.3 & 2.7 & $\begin{array}{l}\text { emulsion } \\
\text { polymerization }\end{array}$ & 29 \\
\hline 8 & 1-propylphosphonic acid cyclic anhydride & $\mathrm{LiNi}_{0.5} \mathrm{Mn}_{1.5} \mathrm{O}_{4}$ & 4.85 & & purchase & 20 \\
\hline
\end{tabular}

The anhydrides can oxidize prior to the carbonate-based liquid electrolytes during charging to high voltage and polymerize as a stable passivation film between cathode and electrolyte to suppress the electrolyte decomposition, transition metal dissolution, and cathode erosion. Therefore, an enhanced cycling stability and decreased self-discharge can be obtained for $\mathrm{LiNi}_{0.5} \mathrm{Mn}_{1.5} \mathrm{O}_{4}$-based LIBs. Nevertheless, its intrinsic poor conductivity has limited the further application of anhydrides. Furthermore, the addition of anhydride monomer would cause capacity loss as the anhydride might react with $\mathrm{Li}^{+}$, cross through the separator and deposit on the surface of Li foil during cycling. Poly(methyl methacrylate) (PMMA), also known as acrylic or acrylic glass, is a transparent thermoplastic resin often used in sheet form as a lightweight or alternative to glass. It can be utilized as casting resin, inks, coating component and so on. PMMA was first discovered as polymer electrolyte for LIBs application in $1985 .^{24}$ The as-obtained results have shown that the ester group can make a contribution to fast lithium ion transportation due to its strong interaction with oxygen group in carbonate and the resultant large amount of electrolyte uptake. ${ }^{25}$ In addition, the segments in PMMA show better interfacial compatibility with lithium metal when compared with other polymers. ${ }^{26}$ However, the anodic stability of the reported PMMA electrolyte is less than $4.8 \mathrm{~V}^{27}$ which fails to meet the working requirement of $\mathrm{LiNi}_{0.5} \mathrm{Mn}_{1.5} \mathrm{O}_{4}$. Furthermore, the mechanical strength of PMMA without crosslinking is not stiff enough to inhibit lithium dendrite penetration.

In this case, inspired by "Shuangiian hebi", which is a statement in traditional Chinese Kungfu story similar to the synergetic effect of $1+1>2$, we propose to combine acrylic anhydride and methyl methacrylate in rigid cross-linking gel polymer electrolyte with the help of cross-linking agent 2methyl-acrylic acid-2-oxirane-ethyl ester. Here, "Shuangjian hebi" denotes not only the obtained cross-linking gel polymer electrolyte with synergetic multiadvantages, such as the generated cross-linking structure to suppress lithium dendritic, flexible lithium ion transport, high voltage resistance, and enhanced mechanical strength endowed by anhydride and acrylate, respectively, but also the in situ polymerization catalyzed by two monomer solutions each other. Thus, an in situ generated cross-linking polymer with excellent contact and superior binding with both electrodes will be achieved compared with those polymer electrolytes listed in Table 1 made via an ex situ polymerization method. Most importantly, surface side effect, lack of reproducibility, tedious and solvents consuming existed in ex situ polymerization methods could be avoided during in situ polymerization. ${ }^{28,29}$

In this work, cross-linking poly(acrylic anhydride-2-methylacrylic acid-2-oxirane-ethyl ester-methyl methacrylate) (PAMM) based electrolyte was synthesized for high voltage LIBs. To evaluate the advantageous performance of in situ cross-linking PAMM, the electrolyte of PMMA was presented for a fair comparison. We performed a comprehensive research on the electrochemical performance of the cross-linking PAMM as well as PMMA in $\mathrm{LiNi}_{0.5} \mathrm{Mn}_{1.5} \mathrm{O}_{4} / \mathrm{Li}$ half-cells at room temperature and $55{ }^{\circ} \mathrm{C}$. Furthermore, the electrochemical properties of $\mathrm{LiNi}_{0.5} \mathrm{Mn}_{1.5} \mathrm{O}_{4} / \mathrm{Li}_{4} \mathrm{Ti}_{5} \mathrm{O}_{12}$ full cells using this cross-linking PAMM-based electrolyte were presented to demonstrate the huge advantages of high voltage resistance and interfacial compatibility even in harsh conditions provided by the synergetic effect of acrylic anhydride and methyl methacrylate.

\section{EXPERIMENTAL SECTION}

Synthesis of PAMM. All chemicals, battery-grade $\mathrm{LiPF}_{6}$, ethylene carbonate (EC), diethyl carbonate (DEC), methyl methacrylate monomer (MMA), acrylic anhydride, 2-methyl-acrylic acid-2-oxiraneethyl ester (MAEOE), azobis(isobutyronitrile) (AIBN), and methyl ethyl carbonate (MEC), were purchased from Aldrich and used as received. The PAMM was synthesized in glovebox by an in situ polymerization method. The $60 \mathrm{wt} \%$ electrolyte of $1 \mathrm{M} \mathrm{LiPF}_{6}$ in EC/ $\operatorname{DEC}(1: 1, \mathrm{v} / \mathrm{v})$ with $30 \mathrm{wt} \%$ MMA monomer and $10 \mathrm{wt} \%$ acrylic anhydride was prepared and marked as solution A. The electrolyte of MAEOE with $1 \mathrm{wt} \%$ AIBN in MEC stored at low temperature was marked as solution B. Solutions A and B were mixed with volume ratio of $1: 1$ with a water content value of $30 \mathrm{ppm}$. Free radical reaction and acid catalyzed ring-opening reaction happened at the onset of blending. $\mathrm{LiPF}_{6}$ in solution A would act with trace of water and generate $\mathrm{PF}_{5}$. The resultant $\mathrm{PF}_{5}$ acted as Lewis acid and then catalyzed ring-opening reaction of MAEOE immediately and formed crosslinking points. In the meantime, the double bond in MAEOE will react with methyl methacrylate and acrylic anhydride with the addition of AIBN at $50{ }^{\circ} \mathrm{C}$. After heating for $6 \mathrm{~h}$, a polymer network of PAMM with multiadvantages was obtained finally. As a contrast, PMMA electrolyte was prepared by mixing MMA monomer, $1 \mathrm{M} \mathrm{LiPF}_{6}$ in EC/DEC (1:1, v/v) and AIBN in ratio of 1:2.5:0.5\%. poly(ethylene terephthalate) (PET) separators (FPB1511) were used as substrate.

Characterization. Scanning electron microscopy (SEM, Hitachi S4800 at $3 \mathrm{kV}$ ) was taken to observe the surface morphology of the electrolyte and electrodes. Fourier Transform Infrared spectrum (FTIR, Bruker VERTEX 70) and X-ray diffraction (XRD, Ultima IV) tests were used to evaluate the chemical structures and crystallinity degree of PAMM, respectively. Inductively coupled plasma (ICP, Optima 8300 ) test was conducted to detect the concentration of dissolved manganese ions in PMMA and cross-linking PAMM-based electrolyte. $\mathrm{X}$-ray photoelectron spectroscopy (XPS, ESCALab220i-XL) and 
(a)

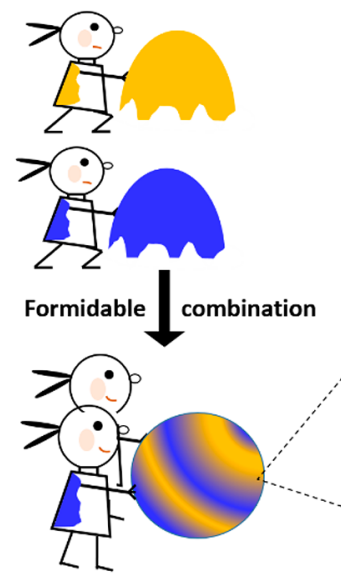

(b)

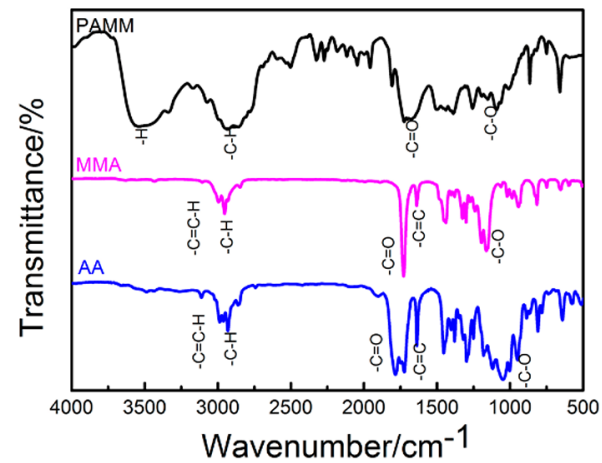

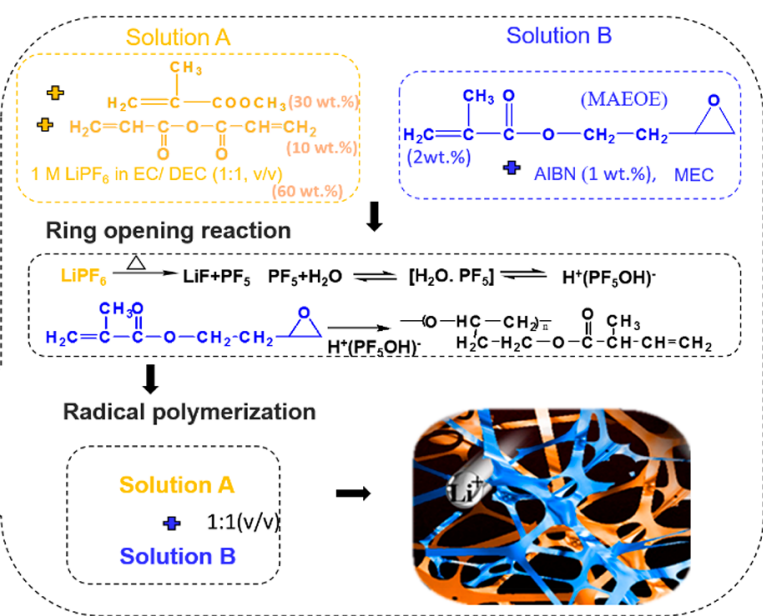

(c)

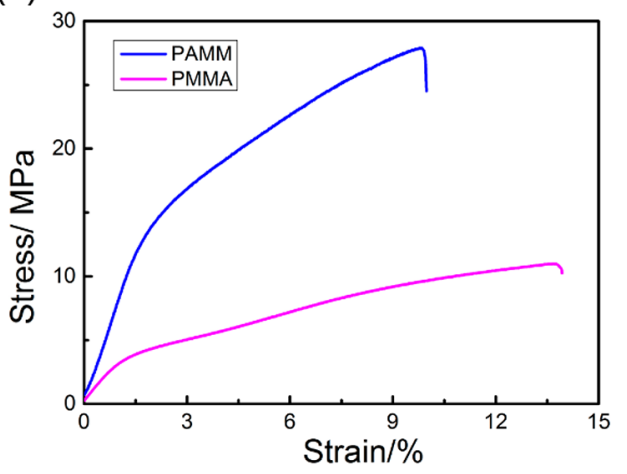

Figure 1. (a) Scheme of "Shuangjian hebi" reaction; (b) Infrared absorbance spectra of AA, MMA, and PAMM; (c) Stress-strain curves for PMMA and PAMM.

transmission electron microscopy (TEM, Tecnai G20, FEI) were used to characterize the surface element composition and surface morphology. Moreover, the thermogravimetric analysis was conducted by METTLER DSC/TGA1 and the water content was tested by Karl Fischer method (870 KF Titrino plus).

The ionic conductivity tests of cross-linking PAMM between two stainless steels was conducted via the electrochemical impedance spectroscopy (EIS) measurement in the frequency range from $1 \mathrm{~Hz}$ to $1 \mathrm{MHz}$. The lithium ion transference number $\left(t_{\mathrm{Li}+}\right)$ was calculated according to following equation

$$
t_{\mathrm{Li}+}=I_{\mathrm{s}}\left(\Delta V-I_{0} R_{\mathrm{s}}\right) / I_{0}\left(\Delta V-I_{\mathrm{s}} R_{0}\right)
$$

Where $I_{0}$ and $I_{S}$ represent initial and steady-state current values, whereas $R_{0}, R_{S}$ indicate the resistance of initial and steady state, respectively. $\Delta V$ is the potential amplitude of $10 \mathrm{mV}$. The linear sweep voltammetry conducted on a stainless steel working electrode and lithium metal as counter electrode at the scan rate of $1 \mathrm{mV} \mathrm{s}^{-1}$ over the potential range of $0-6.0 \mathrm{~V}$ versus $\mathrm{Li}^{+} / \mathrm{Li}$. The cathode pasted on an $\mathrm{Al}$ foil was composed of $90 \mathrm{wt} \% \mathrm{LiNi}_{0.5} \mathrm{Mn}_{1.5} \mathrm{O}_{4}, 4 \mathrm{wt} \%$ carbon black, and 6 wt \% poly(vinylidene fluoride) (PVDF). The anode was fabricated by blending the active material of $\mathrm{Li}_{4} \mathrm{Ti}_{5} \mathrm{O}_{12}$, carbon black conductive agent and PVDF binder in the weight ratio of 92:3:5. The active material loading was $1.8 \mathrm{mg} \mathrm{cm}{ }^{-2}$. The 2032-type coin cells were assembled where $\mathrm{LiNi}_{0.5} \mathrm{Mn}_{1.5} \mathrm{O}_{4}$ was used as cathode and $\mathrm{Li}$ or $\mathrm{Li}_{4} \mathrm{Ti}_{5} \mathrm{O}_{12}$ as counter electrode, respectively, whereas coin-type $\mathrm{LiNi}_{0.5} \mathrm{Mn}_{1.5} \mathrm{O}_{4} / \mathrm{LiTi}_{5} \mathrm{O}_{12}$ full cells with PAMM-based gel electrolytes was constructed with $\mathrm{N} / \mathrm{P}$ values of ca. 1.2 (calculated according to $147 \mathrm{mAh} \mathrm{g}^{-1}$ and $150 \mathrm{mAh} \mathrm{g}^{-1}$ for $\mathrm{LiNi}_{0.5} \mathrm{Mn}_{1.5} \mathrm{O}_{4}$ and $\mathrm{LiTi}_{5} \mathrm{O}_{12}$, respectively) in an argon-filled glovebox. The in situ polymerization were completed in glovebox filled with argon, where oxygen and water content was controlled less than $0.1 \mathrm{ppm}$. The coin cells injected with PMMA electrolyte were assembled for comparison. The cells were galvanostatically charged and discharged at different rates in the voltage range between 3.5 and $5.0 \mathrm{~V}\left(\mathrm{vs} \mathrm{Li}^{+} / \mathrm{Li}\right)$ by a Land battery test system (Land CT2001A, Wuhan Land Electronic Co. Ltd., China).

\section{RESULTS AND DISCUSSION}

In Situ Polymerization and Characterization of CrossLinking PAMM. Cross-linking PAMM-based electrolyte with multiadvantages of individual polymer was designed by the inspiration of "Shuangjian hebi". The reaction details were depicted in Figure 1a according to previous reports on the related mechanism. ${ }^{30-32}$ Specifically, in MAEOE circuit opening part, $\mathrm{PF}_{5}$ was used as a common cationic polymerization initiator, which could react with the trace water $(30 \mathrm{ppm}$ in system, compared with $14.6 \mathrm{ppm}$ in literature) in the precursor solution $\mathrm{A}$ and form $\mathrm{H}^{+}\left(\mathrm{PF}_{5} \mathrm{OH}\right)^{-}$to further initiate the gelation reaction. ${ }^{33}$ Free radical reaction and acid-catalyzed ring-opening reaction occurred at the clicking of mixing solution $\mathrm{A}$ and $\mathrm{B}$. The $\mathrm{H}^{+}\left(\mathrm{PF}_{5} \mathrm{OH}\right)^{-}$acted as Lewis acid and catalyzed the ring-opening of 2-methyl-acrylic acid-2oxirane-ethyl ester (MAEOE), and then formed a cross-linking site. Simultaneously, free radical reaction happened between acrylic anhydride, methyl methacrylate, and the double bond of newly generated cross-linking MAEOE and formed a polymer network structure (Figure S1). In the FTIR spectra (Figure $\mathrm{lb})$, the bands at 1092 and $1152.47 \mathrm{~cm}^{-1}$ corresponded to the coupled vibration of $(\mathrm{O}=\mathrm{C}-\mathrm{O}-\mathrm{C}=\mathrm{O})$. The strong absorbing bands at 1724 and $1165 \mathrm{~cm}^{-1}$ corresponded to $(\mathrm{C}=\mathrm{O})$ and $\left(\mathrm{O}-\mathrm{CH}_{3}\right)$, respectively. The absorbing bands at $2960 \mathrm{~cm}^{-1}$ were assigned to $(-\mathrm{C}-\mathrm{H})$. The polymerization of acrylic 

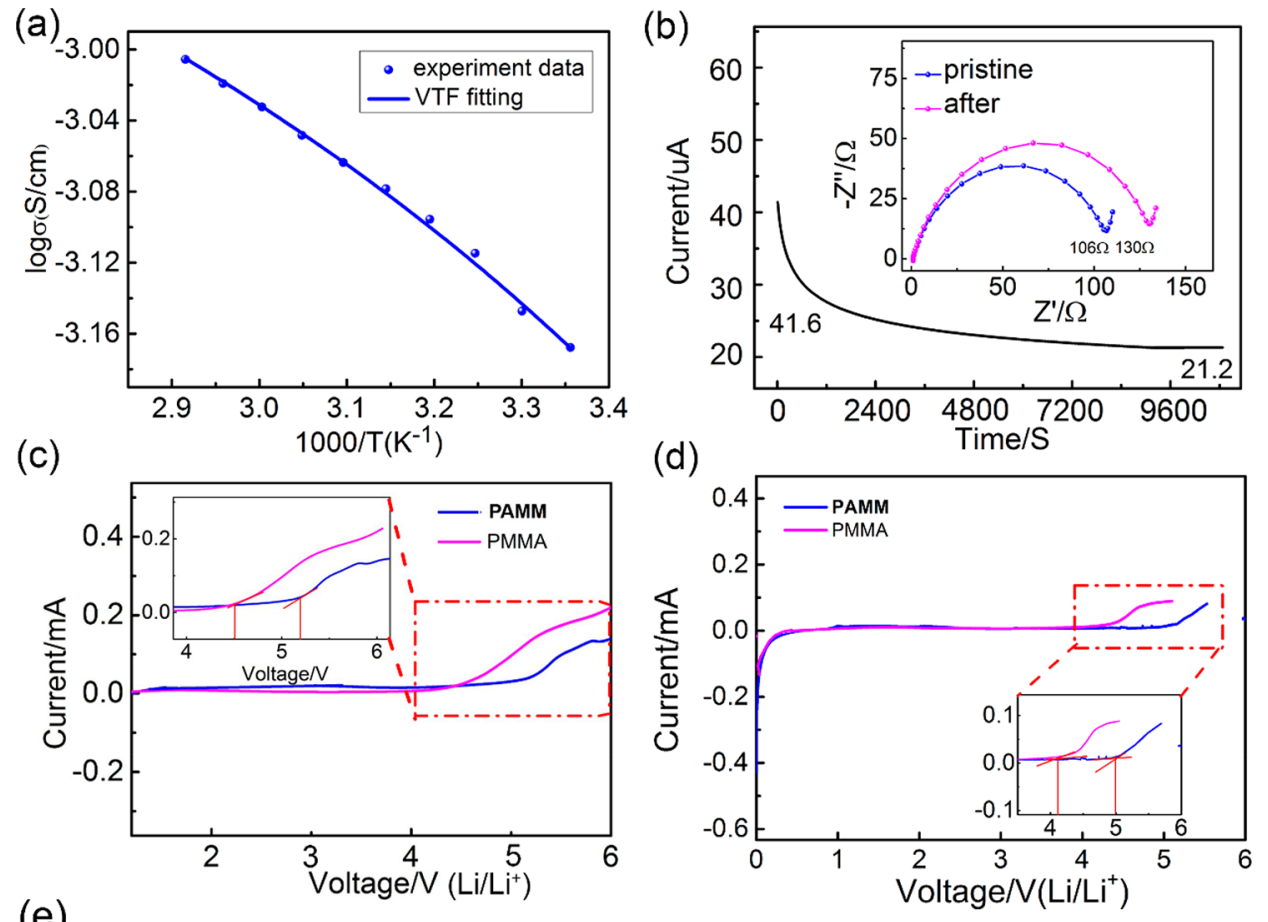

(e)

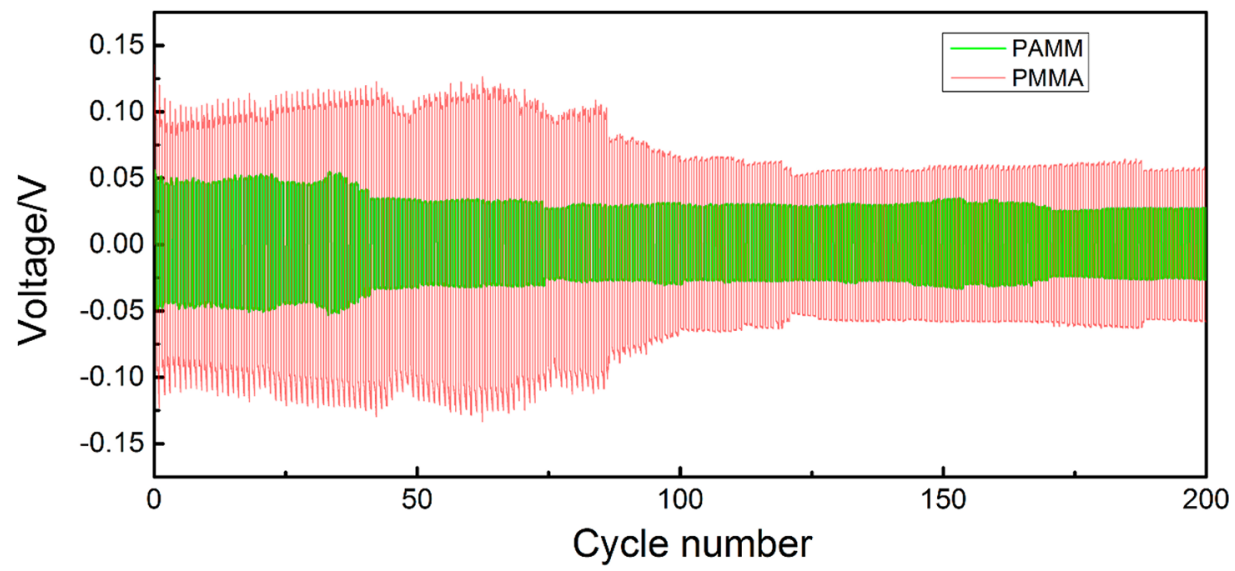

Figure 2. (a) Ionic conductivity dependence with temperature of cross-linking PAMM and (b) Current-time profiles following a DC polarization of $0.01 \mathrm{~V}$ of the cross-linking PAMM. Inset is Nyquist profiles of the cell before and after polarization. Comparison of linear sweep voltammograms of PAMM and PMMA at a scan rate of $1 \mathrm{mV} \mathrm{s}^{-1}$ at (c) room temperature and (d) $55^{\circ} \mathrm{C}$, and (e) Chronopotentiometry profiles of PAMM and PMMA in $\mathrm{Li} / \mathrm{Li}$ symmetric cells.

anhydride, methyl methacrylate and cross-linked MAEOE was demonstrated by the absence of unsaturated $-\mathrm{C}=\mathrm{C}-$ groups and epoxy group in the FTIR spectra (Figure 1b). The schematic design of PAMM polymer was shown in Figure S1a. Benefiting from the in situ polymerization process, the obtained gel polymer electrolyte had smooth and homogeneous surface morphology and well contact with electrode material (Figure S1b, c). Furthermore, the cross-linking PAMM-based electrolyte had much greater mechanical strength $(27.5 \mathrm{MPa})$ than that of PMMA polymer (10.2 MPa), as depicted in the stressstrain curves in Figure 1c. ${ }^{34,35}$ Moreover, the thermogravimetric analysis results of PAMM and PMMA were displayed in Figure S2a, b. The comparison of burning tests on polypropylene (PP), glass fiber (GF), cellulose separators immersed with liquid electrolyte and cross-linking PAMM were demonstrated in Figure S2c, indicating the increase of thermal stability and the best flame-retarding property of PAMM.
Besides the above merits, the amorphous structure of PAMM (Figure S3) would also have flexible pathway for lithium transport. The ion-conductive behavior at different temperature from 273 to $353 \mathrm{~K}$ was depicted in Figure 2a. A distinct curvature was exhibited especially in the low temperature region, which can be described by empirical Vogel-TammanFulcher (VTF) equation:

$$
\sigma(T)=A T^{-1 / 2} \exp \left(E_{\mathrm{a}} / R\left(T-T_{0}\right)\right)
$$

$R$ is a gas constant, $A$ is the pre-exponential factor, $T_{0}$ is the temperature correlated to the glass transition temperature, which is called equilibrium glass transition temperature, $E_{\mathrm{a}}$ is the activation energy. It was worth noticing that the $E_{a}$ value was calculated to be $1 \mathrm{~kJ} \mathrm{~mol}^{-1}$, a value lower than that of traditional gel electrolyte $\left(10 \mathrm{~kJ} \mathrm{~mol}^{-1}\right)$ and solid electrolyte $\left(40 \mathrm{~kJ} \mathrm{~mol}^{-1}\right){ }^{29,36,37}$ A conductivity value of $6.79 \times 10^{-4} \mathrm{~S}$ $\mathrm{cm}^{-1}$ was achieved at room temperature, which was attributed to the low energy barrier. ${ }^{38}$ The high ionic conductivity value 
(a)
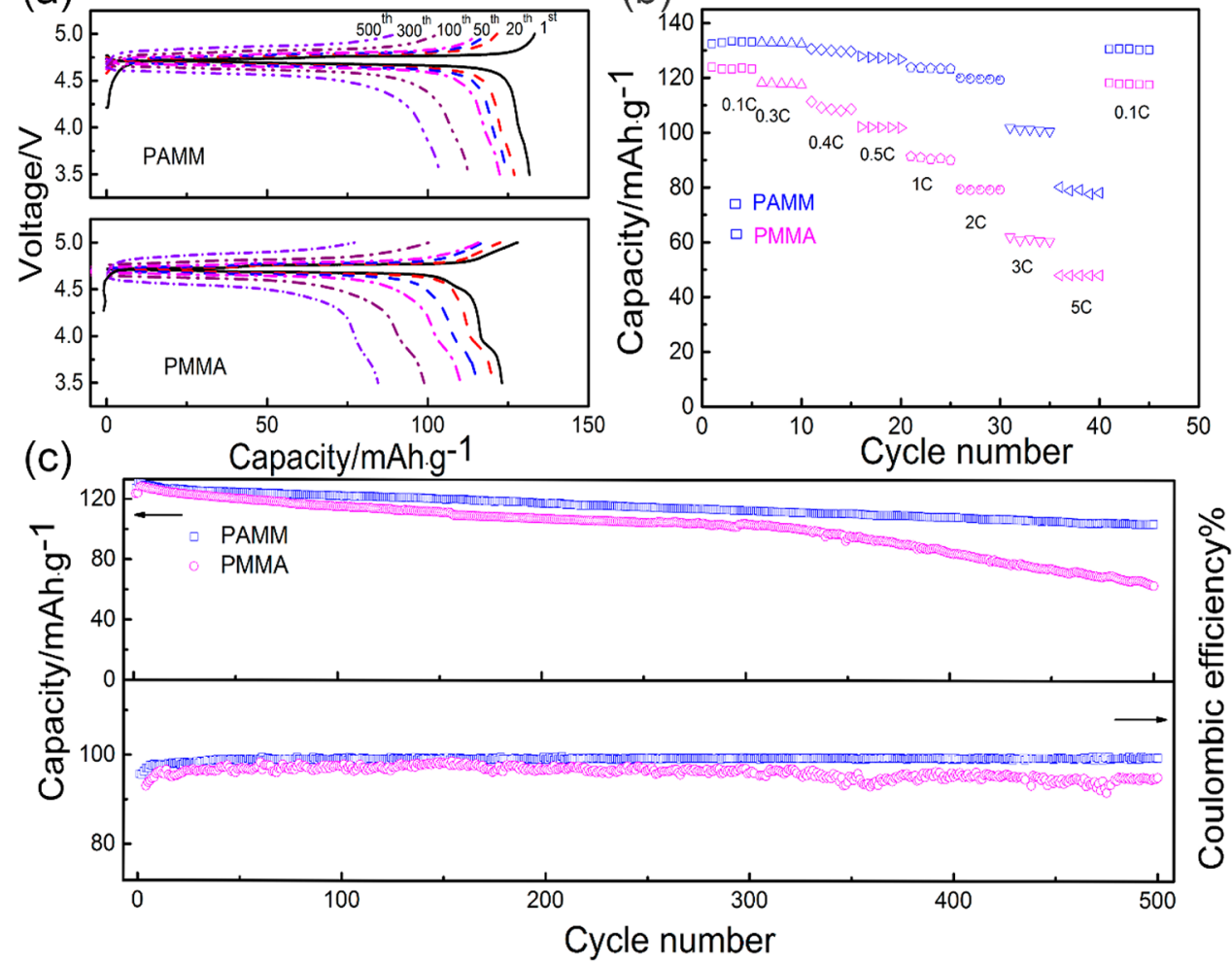

(b)

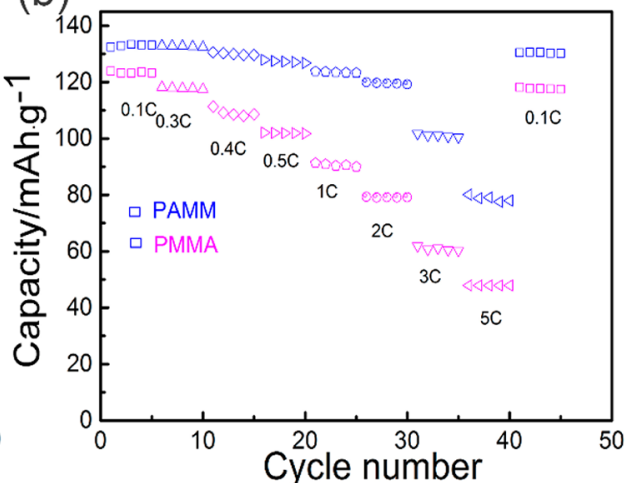

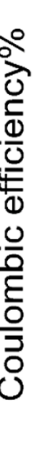

Figure 3. (a) Charge-discharge profiles with cross-linking PAMM and PMMA from the 1st to 500th at different cycles. (b) Discharge capacity and Coulombic efficiency of $\mathrm{LiNi}_{0.5} \mathrm{Mn}_{1.5} \mathrm{O}_{4} / \mathrm{Li}$ cells using the PAMM and PMMA at $0.1 \mathrm{C}$. (c) Rate capability of $\mathrm{LiNi}_{0.5} \mathrm{Mn}_{1.5} \mathrm{O}_{4} / \mathrm{Li}_{\text {cells }}$ with PAMM and PMMA at $25^{\circ} \mathrm{C}$.

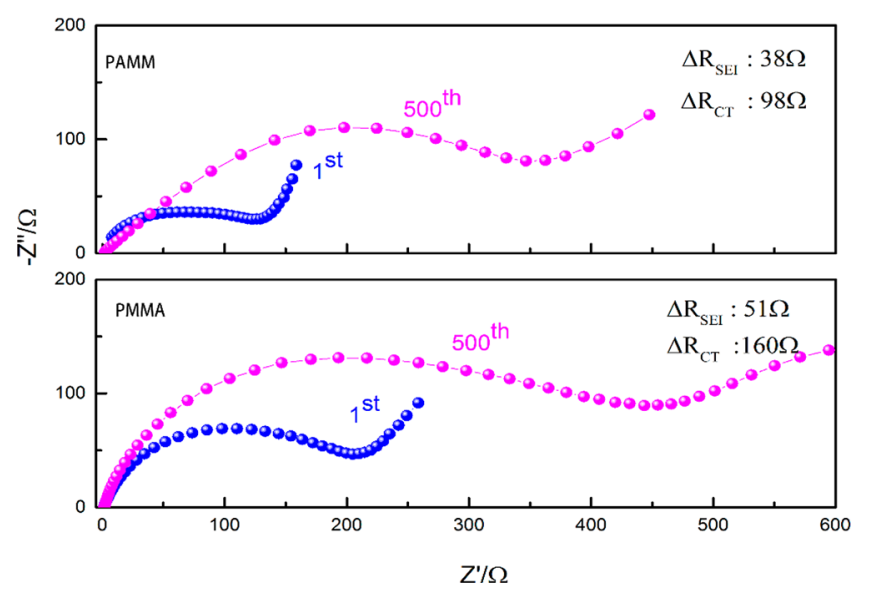

Figure 4. Impedance variation after 500 cycles of $\mathrm{LiNi}_{0.5} \mathrm{Mn}_{1.5} \mathrm{O}_{4} / \mathrm{Li}$ cell assembled with PAMM- and PMMA-based electrolyte.

may result from the soft segments of PMMA and the plasticization of carbonate solvent ${ }^{39-41}$ and the relevant impedance spectra at different temperature were depicted in Figure S4.

As depicted in Figure 2b, a remarkable lithium ion transference number $\left(t_{\mathrm{Li}+}\right)$ value of 0.51 for cross-linking PAMM was obtained. The high $t_{L i+}$ can effectively reduce the polarization in the charging/discharging process, thus favorably improve the power density. In Figure 2c, d, linear sweep voltammetry was used to contrast the electrochemical stability window of PMMA and cross-linking PAMM-based electrolyte at room temperature. PMMA-based one decomposed at around

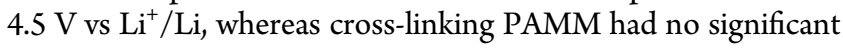

decomposition current up to $5.2 \mathrm{~V}$ vs $\mathrm{Li}^{+} / \mathrm{Li}$. When the temperature was elevated to $55{ }^{\circ} \mathrm{C}$, the PAMM-based electrolyte maintained electrochemical stability up to $5.0 \mathrm{~V}$ because of the synergistic effect of the formation of crosslinking structure and the addition of anhydride, which works as anti-high voltage resistant component, while PMMA began to decompose around $4.0 \mathrm{~V}$. It was indicated that the cross-linking PAMM was relatively chemical inert at high voltage of $5 \mathrm{~V}$ vs $\mathrm{Li}^{+} / \mathrm{Li}$, which endowed it very promising polymer electrolyte for high voltage batteries. The linear sweep voltammetry of PAA was also showed in Figure S5 as a comparison, it deposed at $5.0 \mathrm{~V}$ vs $\mathrm{Li}^{+} / \mathrm{Li}$. The interfacial compatibility of PAMM and PMMA based electrolyte with $\mathrm{Li}$ foil was compared by conducting symmetric cells test under a current density of $0.2 \mathrm{~mA} \mathrm{~cm}^{-2}$ and the result was shown in Figure 2e. The cell with PAMM maintained stable Li plating/stripping during the entire process and demonstrated an extraordinary cycling stability. A small polarization was observed after cycling for 200 cycles and no sign of short cut appeared, indicating a smooth and flat interface of lithium anode, which will be proved in the following sections. By a sharp contrast, PMMA symmetric cell showed a more severely polarization, demonstrating an unstable surface and a poor lithium deposition/striping. The long cycling performance of PAMM symmetric cell was conducted at density of $0.2 \mathrm{~mA} \mathrm{~cm}^{-2}$ for 1000 cycles to verify the stable $\mathrm{Li}$ plating/stripping in Figure S6. A stable charge and discharge curve was showed and demonstrated a relatively stable interface formed under the effect of "Shuangiian hebi". In addition, the interfacial chemical compatibility of $\mathrm{Li} /$ cross-linking PAMM/Li and $\mathrm{Li} / \mathrm{PMMA} / \mathrm{Li}$ were also evaluated by analyzing the $\mathrm{AC}$ impedance variation with elapsed time (Figure S7), which 


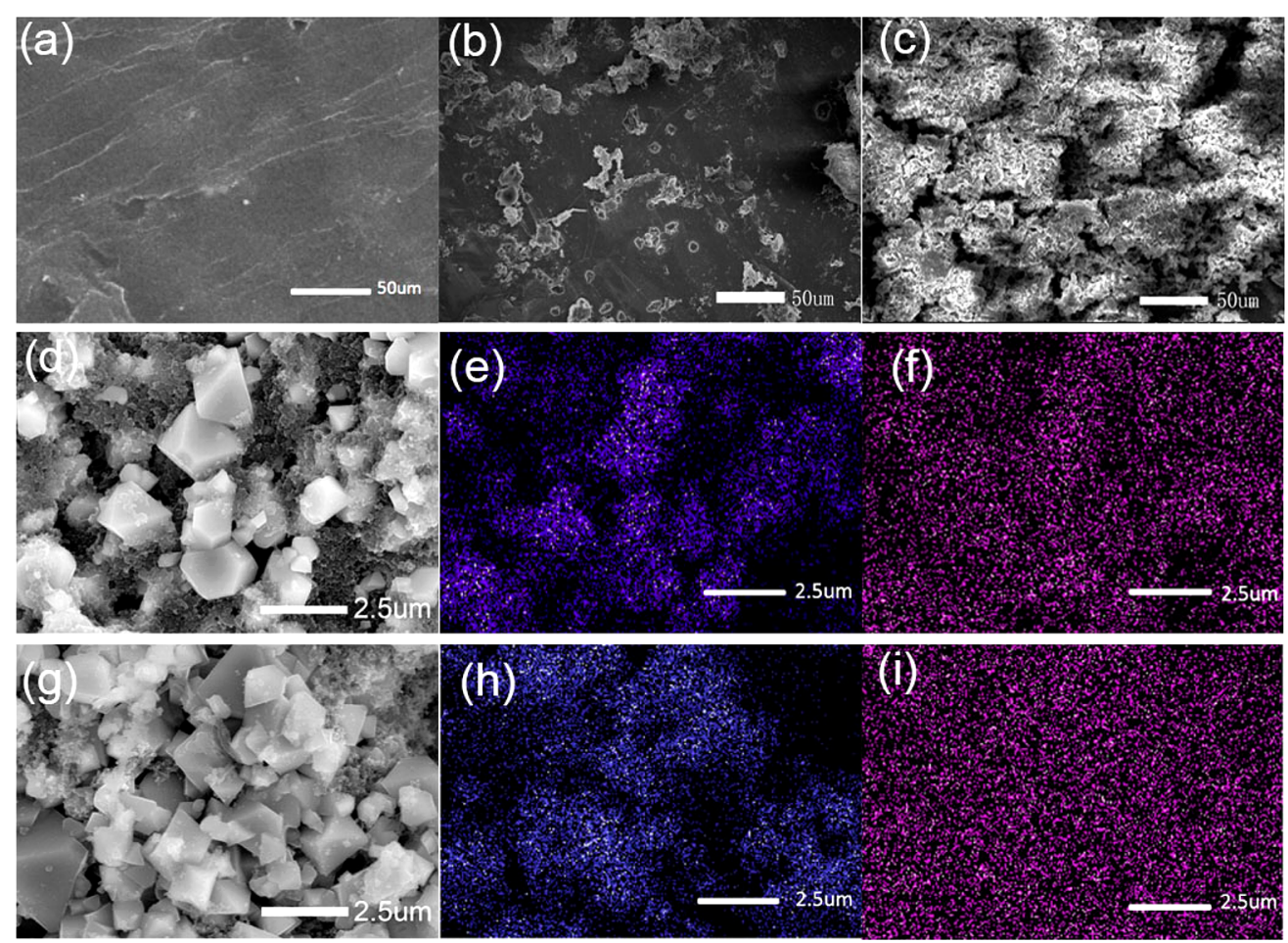

Figure 5. Typical SEM images of (a) pristine Li foil, (b) Li foil in PAMM half-cell, and (c) in PMMA half-cell after 500 cycles; (d) $\mathrm{LiNi}_{0.5} \mathrm{Mn}_{1.5} \mathrm{O}_{4}$ cycled with PAMM and related mapping photos: (e) $\mathrm{O}$ and (f) $\mathrm{Mn}$ element; (g) $\mathrm{LiNi}_{0.5} \mathrm{Mn}_{1.5} \mathrm{O}_{4}$ cycled with PMMA and related mapping photos: (h) $\mathrm{O}$ and (i) Mn element.

indicated the high interface stability between cross-linking PAMM and Li metal after 30 days standing.

Electrochemical Properties of $\mathrm{LiNi}_{0.5} \mathrm{Mn}_{1.5} \mathrm{O}_{4} /$ CrossLinking PAMM/Li Cells. To further investigate the feasibility of cross-linking PAMM in high voltage LIBs, the electrochemical behaviors of $\mathrm{LiNi}_{0.5} \mathrm{Mn}_{1.5} \mathrm{O}_{4} / \mathrm{Li}$ cells using crosslinking PAMM and PMMA electrolytes cycled between 3.5 and $5.0 \mathrm{~V}$ at room temperature were displayed in Figure 3. As shown in Figure 3a, the voltage plateau in both cells was consistent with the typical $\mathrm{LiNi}_{0.5} \mathrm{Mn}_{1.5} \mathrm{O}_{4}$ charge-discharge profiles. ${ }^{42}$ Nevertheless, the voltage gap between charge and discharge profiles of $\mathrm{LiNi}_{0.5} \mathrm{Mn}_{1.5} \mathrm{O}_{4} / \mathrm{PMMA} / \mathrm{Li}$ cell increased dramatically during cycling, compared with slightly increased $\mathrm{LiNi}_{0.5} \mathrm{Mn}_{1.5} \mathrm{O}_{4} / \mathrm{PAMM} / \mathrm{Li}$ cell. This result indicated PAMMbased electrolyte can endow a superior interfacial compatibility and suppress the polarization of $\mathrm{LiNi}_{0.5} \mathrm{Mn}_{1.5} \mathrm{O}_{4} / \mathrm{Li}$ cell remarkably, ${ }^{43}$ which was proved by the improved cycling performance of $\mathrm{LiNi}_{0.5} \mathrm{Mn}_{1.5} \mathrm{O}_{4} / \mathrm{PAMM} / \mathrm{Li}$ cell (Figure $3 \mathrm{~b}$ ). The first reversible capacity for $\mathrm{LiNi}_{0.5} \mathrm{Mn}_{1.5} \mathrm{O}_{4} / \mathrm{PAMM} / \mathrm{Li}$ cell was $131.7 \mathrm{mAh} \mathrm{g}^{-1}$. After 500 cycles, the discharge capacity was still $104 \mathrm{mAh} \mathrm{g}^{-1}$, corresponding to the capacity retention of 78.9\%. As for $\mathrm{LiNi}_{0.5} \mathrm{Mn}_{1.5} \mathrm{O}_{4} / \mathrm{PMMA} / \mathrm{Li}$ cell, the first discharge capacity was up to $123.1 \mathrm{mAh} \cdot \mathrm{g}^{-1}$ but only $78.1 \mathrm{mAh} \cdot \mathrm{g}^{-1}$ (63.44\%) remained after 500 cycles. In addition, the average overall Coulombic efficiency of $\mathrm{LiNi}_{0.5} \mathrm{Mn}_{1.5} \mathrm{O}_{4} / \mathrm{PAMM} / \mathrm{Li}$ (98\%) was better than that of PMMA based cell (95\%). The lower Coulombic efficiency corresponded to the decomposition of solvent and the negative reactions brought by $\mathrm{Mn}$ dissolution. After 300 cycles, the Coulombic efficiency curve of PMMA become confused and corresponded to the capacity fading in cycle-capacity profiles. To verify the synthetic effect of PAMM electrolyte on the cycling performance, the capacity retention for $\mathrm{LiNi}_{0.5} \mathrm{Mn}_{1.5} \mathrm{O}_{4} / \mathrm{Li}$ cells with PAMM, PMMA, and
PAA were compared in Figure S8. PMMA and PAA showed the least capacity retention, which might be caused by the oxidation decomposition of PMMA and the destruction of anhydride to $\mathrm{Li}$ metal, respectively. It was demonstrated that the parasitic reactions related with capacity fading were greatly suppressed by cross-linking PAMM-based electrolyte conducted by the design concept of "shuangjian hebi".

We tracked the rate performances of $\mathrm{LiNi}_{0.5} \mathrm{Mn}_{1.5} \mathrm{O}_{4} / \mathrm{Li}$ cell with cross-linking PAMM and PMMA electrolyte in Figure 3c. For $\mathrm{LiNi}_{0.5} \mathrm{Mn}_{1.5} \mathrm{O}_{4} / \mathrm{PAMM} / \mathrm{Li}$ cell, the discharge capacity in the first fifth cycle at $0.1 \mathrm{C}$ was $132 \mathrm{mAh} \mathrm{g}^{-1}$ and retained 78.5 $\mathrm{mAh} \mathrm{g}^{-1}$ at $5 \mathrm{C}$. When the rate returned back to $0.1 \mathrm{C}$, the capacity of $129.5 \mathrm{mAh} \mathrm{g}^{-1}$ was recovered. By a sharp contrast, the battery with PMMA delivered a capacity of $122.3 \mathrm{mAh} \mathrm{g}^{-1}$ at $0.1 \mathrm{C}$, but only $52 \mathrm{mAh} \mathrm{g}^{-1}$ capacity was delivered at the high rate of $5 \mathrm{C}$. The capacity recovered to $117.6 \mathrm{mAh} \mathrm{g}^{-1}$ in the following cycles at the rate of $0.1 \mathrm{C}$. The improved rate capability of $\mathrm{LiNi}_{0.5} \mathrm{Mn}_{1.5} \mathrm{O}_{4} / \mathrm{PAMM} / \mathrm{Li}$ might be ascribed to the flexible lithium ion transfer, the high voltage resistance and the good interfacial compatibility provided by acrylate and anhydride groups of the in situ polymerized cross-linking PAMM.

Generally, the elevated temperature will facilitate the carbonate solvent decomposition at high potential in LIBs. As a result, the capacity deterioration would be accelerated at elevated temperatures $\left(\geq 50{ }^{\circ} \mathrm{C}\right),{ }^{44,45}$ which was a main obstacle limiting the widespread applications of high-voltage $\mathrm{LiNi}_{0.5} \mathrm{Mn}_{1.5} \mathrm{O}_{4}$. Therefore, the synergistic effects of PAMMbased electrolyte were further expected at the elevated temperature of $55{ }^{\circ} \mathrm{C}$ (Figure S9). As for the cycling characteristics, $\mathrm{LiNi}_{0.5} \mathrm{Mn}_{1.5} \mathrm{O}_{4} / \mathrm{PAMM} / \mathrm{Li}$ delivered a capacity of $110 \mathrm{mAh} \mathrm{g}^{-1}$, which was much higher than that of $89.5 \mathrm{mAh}$ $\mathrm{g}^{-1}$ for PMMA-based battery. After 30 cycles, the PAMM-based 


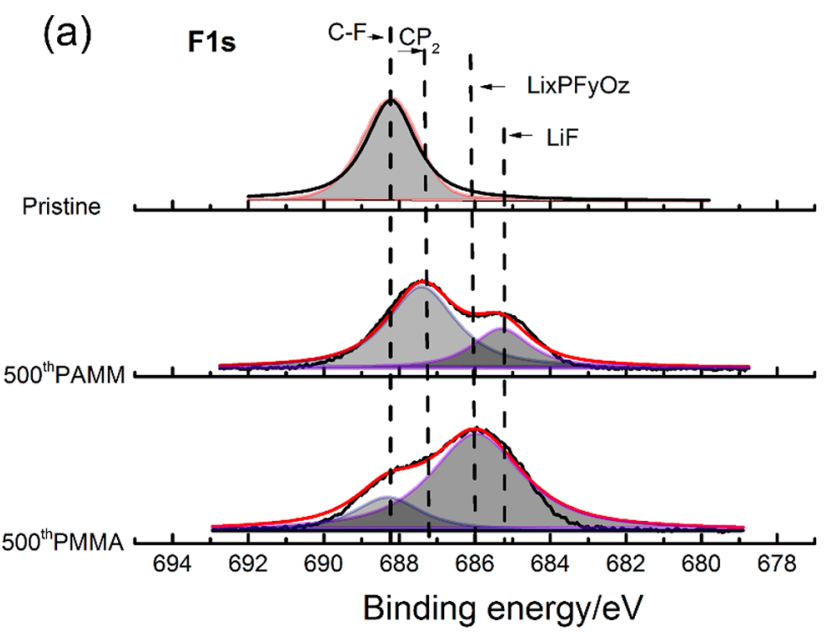

(b)

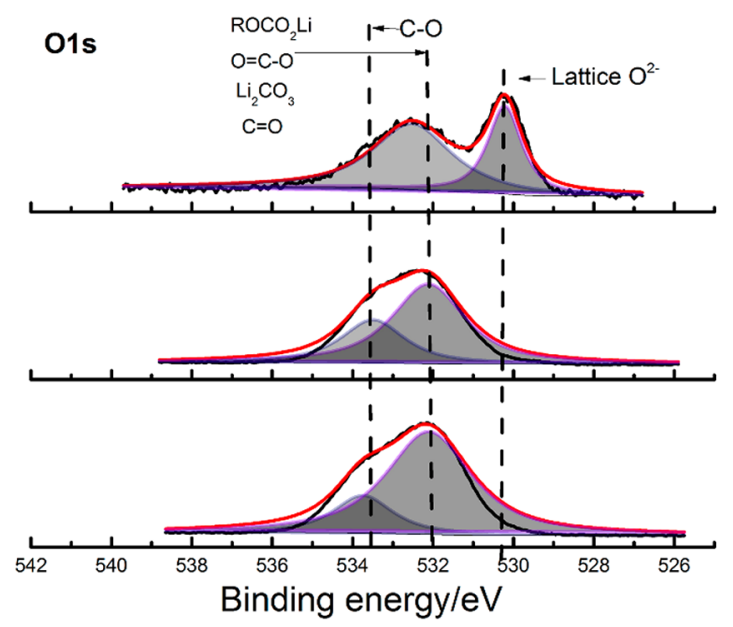

(c)

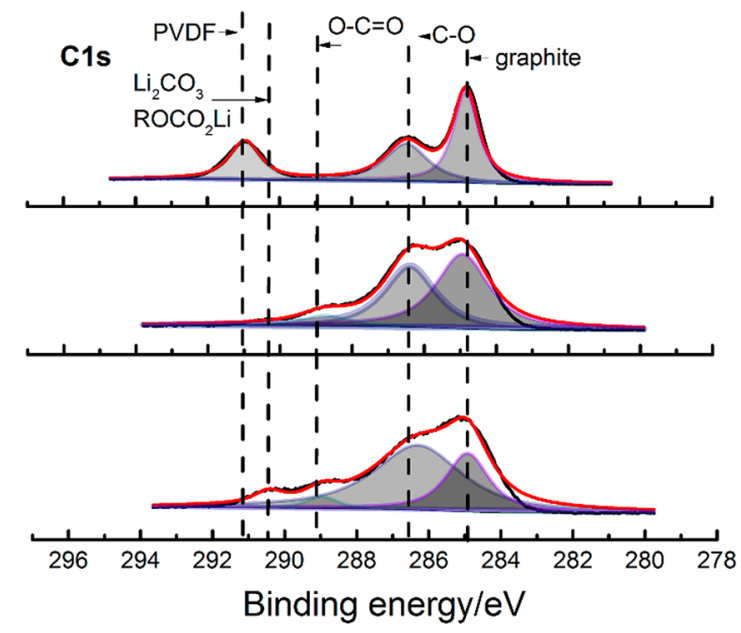

Figure 6. (a) F 1s, (b) O 1s, and (c C 1s) XPS spectra comparison of the pristine and the cycled $\mathrm{LiNi}_{0.5} \mathrm{Mn}_{1.5} \mathrm{O}_{4}$ electrode in PAMM- and PMMA-based electrolytes.

electrolyte maintained the Coulombic efficiency over $92 \%$, whereas the counterpart only $75 \%$ retained (Figure S9). The prior Coulombic efficiency of PAMM-based electrolyte at 55 ${ }^{\circ} \mathrm{C}$ can be attributed to the chemical stability endowed by anhydride and the compatible interface provided by methyl methacrylate. These results proved that PAMM-based electrolyte can significantly enhance the high temperature capacity and cycling stability of $\mathrm{LiNi}_{0.5} \mathrm{Mn}_{1.5} \mathrm{O}_{4} / \mathrm{Li}$ cell.
Interface Compatibility of $\mathrm{LiNi}_{0.5} \mathrm{Mn}_{1.5} \mathrm{O}_{4} /$ Cross-Linking PAMM/Li Cell. Tto further understand the synergistic effects of AA and MMA, we tested the electrochemical impedance spectroscopy (EIS) results (Figure 4) of fully discharged cells of $\mathrm{LiNi}_{0.5} \mathrm{Mn}_{1.5} \mathrm{O}_{4} /$ cross-linking PAMM/Li and $\mathrm{LiNi}_{0.5} \mathrm{Mn}_{1.5} \mathrm{O}_{4} / \mathrm{PMMA} / \mathrm{Li}$. The corresponding fitting results and equivalent electric circuit simulated with $\mathrm{Z}$ Simp Win software were recorded in Table S1. It showed that the cell impedance with PMMA based electrolyte amplified much more $\left(\Delta R_{\mathrm{SEI}} \approx 51 \Omega\right.$ and $\left.\Delta R_{\mathrm{CT}} \approx 160 \Omega\right)$ than that of PAMM-based cell $\left(\Delta R_{\mathrm{SEI}} \approx 38 \Omega\right.$ and $\left.\Delta R_{\mathrm{CT}} \approx 98 \Omega\right)$ after 500 cycles. The high interface impedance of $\mathrm{LiNi}_{0.5} \mathrm{Mn}_{1.5} \mathrm{O}_{4} / \mathrm{PMMA} / \mathrm{Li}$ may leading to the serious polarization during cycling and caused the poor battery performance in Figure 3. This result also indicated the interface between electrodes and PAMM-based electrolyte was much more compatible than that in $\mathrm{LiNi}_{0.5} \mathrm{Mn}_{1.5} \mathrm{O}_{4} / \mathrm{PMMA} / \mathrm{Li}$ cell, which might be owing to the less erosion of electrolyte and the alleviated $\mathrm{Mn}$ dissolution by virtue of the synergistic effect of AA and MMA.

The typical SEM images of pristine Li foil, Li foil in PAMM half-cell and PMMA half-cell after 500 cycles were showed in Figure $5 \mathrm{a}-\mathrm{c}$, respectively. The $\mathrm{Li}$ foil in PAMM half-cell exhibited a smooth and compact surface with little cracks after 500 cycles, whereas the Li foil in PMMA half-cell showed severe impurity accumulation and incompact surface. For high voltage spinel cathode material, the pristine and the cycled $\mathrm{LiNi}_{0.5} \mathrm{Mn}_{1.5} \mathrm{O}_{4}$ electrodes with PAMM and PMMA based electrolytes demonstrated typical spinel crystal morphology (Figure 5d, g). The mapping result (Figure 5e, f, Table S2) of $\mathrm{LiNi}_{0.5} \mathrm{Mn}_{1.5} \mathrm{O}_{4}$ electrode faced with PAMM showed the same $\mathrm{O}$ and $\mathrm{Mn}$ element distribution. In comparison, for $\mathrm{LiNi}_{0.5} \mathrm{Mn}_{1.5} \mathrm{O}_{4}$ electrode assembled with PMMA electrolyte, the $\mathrm{Mn}$ element distributed in the whole observation area rather than in the specific area just like $\mathrm{O}$ element did, suggesting the serious $\mathrm{Mn}$ dissolution from $\mathrm{LiNi}_{0.5} \mathrm{Mn}_{1.5} \mathrm{O}_{4}$. The ICP-MS analysis (Table S3) further confirmed the dissolution of Mn element. Mn ion concentration of 56.2 and $11.0 \mathrm{ppm}$ was obtained at $25^{\circ} \mathrm{C}$ for PMMA and cross-linking PAMM-based electrolyte, respectively, which reflected a more severe Mn dissolution in PMMA-based system after cycling (Figure $5 \mathrm{i}){ }^{46}$ The corresponding value of $\mathrm{Mn}$ ion concentration at $55{ }^{\circ} \mathrm{C}$ was also listed in Table S3, which demonstrated that the higher the temperature, the more $\mathrm{Mn}$ ions dissolved in the PMMA-based cell. The above results indicated that the cross-linking PAMM could not only retard the dissolution of transition metal at severe conditions such as high potential and high temperature but also enhance the interface stability between electrolyte and $\mathrm{Li}$ metal, which confirmed the synergetic effect of AA and MMA.

To further understand the origin of the above difference in impedance evolution and element distribution between PAMM -and PMMA-based electrolyte involved LNMO electrodes, interface composition of the two electrodes after 500 cycles were studied by XPS in Figure 6. At pristine state, $\mathrm{O}$ 1s and $\mathrm{C}$ 1s spectra show characteristic peaks of $\mathrm{LiNi}_{0.5} \mathrm{Mn}_{1.5} \mathrm{O}_{4}$ electrodes. ${ }^{47,48}$ In F 1s spectra for two electrodes (Figure $6 \mathrm{a}$ ), the peak values of $685.2,686,687$, and $688.1 \mathrm{eV}$ belong to $\mathrm{LiF}, \mathrm{Li}_{x} \mathrm{PF}_{y} \mathrm{O}_{z}$ $\mathrm{CP}_{2}$, and $\mathrm{C}-\mathrm{F}$, respectively. The intensity of $\mathrm{LiF}$ increased greatly for PMMA-based electrode, indicating the much severe electrolyte decomposition. In $\mathrm{O} 1 \mathrm{~s}$ and $\mathrm{C}$ 1s spectra, the lattice oxygen peak decreased while the oxygen-carbon peaks increased, demonstrating the formation of cathode electrolyte interphase (CEI) layers on the surface of both electrodes after 
(a)

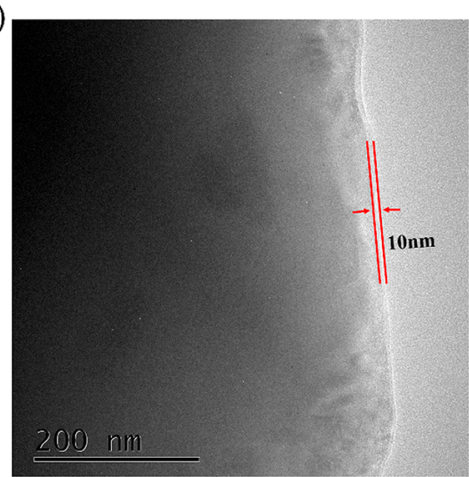

(c)

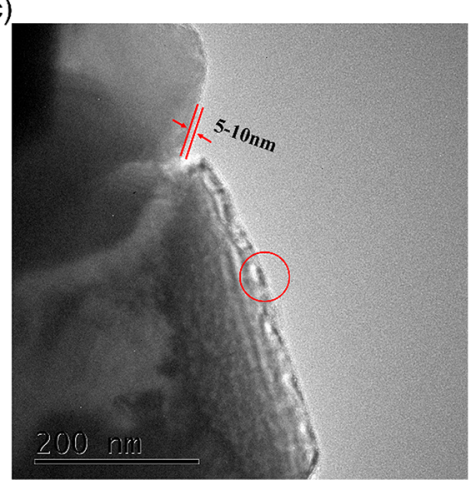

(b)

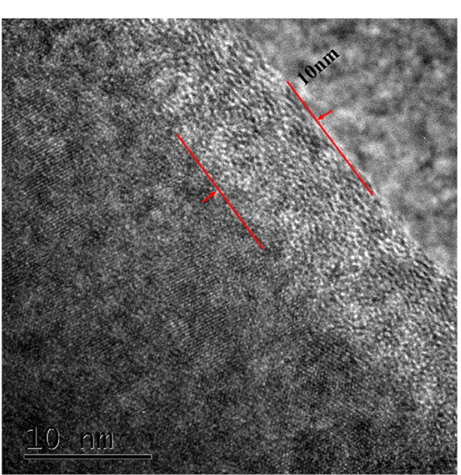

(d)

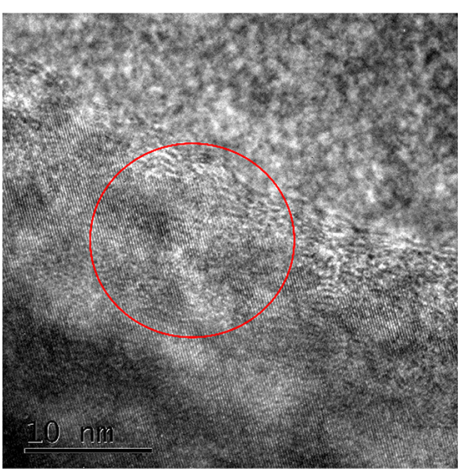

Figure 7. (a, b) TEM micrographs of $\mathrm{LiNi}_{0.5} \mathrm{Mn}_{1.5} \mathrm{O}_{4}$ electrode with PAMM-based electrolyte after 500 cycles at different resolution; (c, d) TEM micrographs of $\mathrm{LiNi}_{0.5} \mathrm{Mn}_{1.5} \mathrm{O}_{4}$ electrode with PMMA electrolyte after 500 cycles.

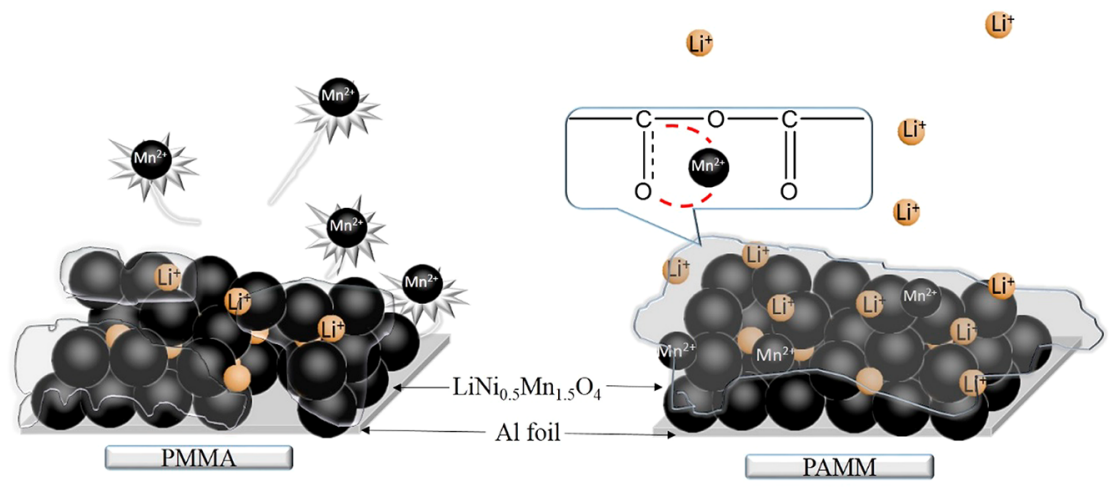

Figure 8. Illustrations of working mechanisms of different electrolytes.

500 cycles. $^{49}$ The peak intensity at $530.4-531.94 \mathrm{eV}$ of both electrodes is regarded as the formation of semicarbonate $(\mathrm{ROCO} 2 \mathrm{Li})$ and carbonate $\left(\mathrm{Li}_{2} \mathrm{CO}_{3}\right)$ species as well as the ester group with carbonate oxygen from decomposition of carbonate solvent. In the $\mathrm{O} 1 \mathrm{~s}$ branch, the spectrum of the PMMA exhibits a more clearly grown peak at around $530 \mathrm{eV}$, indicating more significant decomposition of carbonate solvent. The formation of CEI could equally be deduced from $\mathrm{C} 1 \mathrm{~s}$. The intensity of carbonyl group and alkyl group with carbonate oxygen increased because of the decomposition of carbonate solvent. These results shed light on the CEI composition being similar for two electrodes, and the moderate thickness and integrity of the CEI layer should have a significant effect on the electrode performance.

The TEM images (Figure $7 \mathrm{a}, \mathrm{b}$ ) of the cycled $\mathrm{LiNi}_{0.5} \mathrm{Mn}_{1.5} \mathrm{O}_{4}$ electrode with PAMM-based electrolyte displayed an amorphous surface layer known as CEI with a thickness approximately $10 \mathrm{~nm}$, which is more uniform and compact than that of the $\mathrm{LiNi}_{0.5} \mathrm{Mn}_{1.5} \mathrm{O}_{4}$ electrode with PMMA electrolyte(Figure $7 \mathrm{c}$ and $7 \mathrm{~d}$ ). Furthermore, the covering film on PMMA involved $\mathrm{LiNi}_{0.5} \mathrm{Mn}_{1.5} \mathrm{O}_{4}$ showed a cracked and heterogeneous morphology, indicating an unstable CEI formation. In a conclusion, the intact and robust CEI formed on $\mathrm{LiNi}_{0.5} \mathrm{Mn}_{1.5} \mathrm{O}_{4}$ electrode in PAMM-based electrolyte could facilitate the transfer of lithium ions, alleviate the erosion of electrolyte, repress the transition metal dissolution in cathode, and then significantly improve the performance of LIBs.

The mechanism of "Shuangjian hebi" electrolyte system alleviated $\mathrm{Mn}$ dissolution may be interpreted as follows. The fully charged state $\mathrm{LiNi}_{0.5} \mathrm{Mn}_{1.5} \mathrm{O}_{4}$ would catalyze the decomposition of solvent in PMMA based electrolyte, in return, the dissolution of transition metal and the disproportioned reaction of $\mathrm{Mn}^{2+}$ would be accelerated by electrolyte oxidation. Hence, when cross-linking PAMM-based polymer network was introduced to replace the electrolyte-swelling PMMA-based electrolyte, the electrolyte decomposition will be 


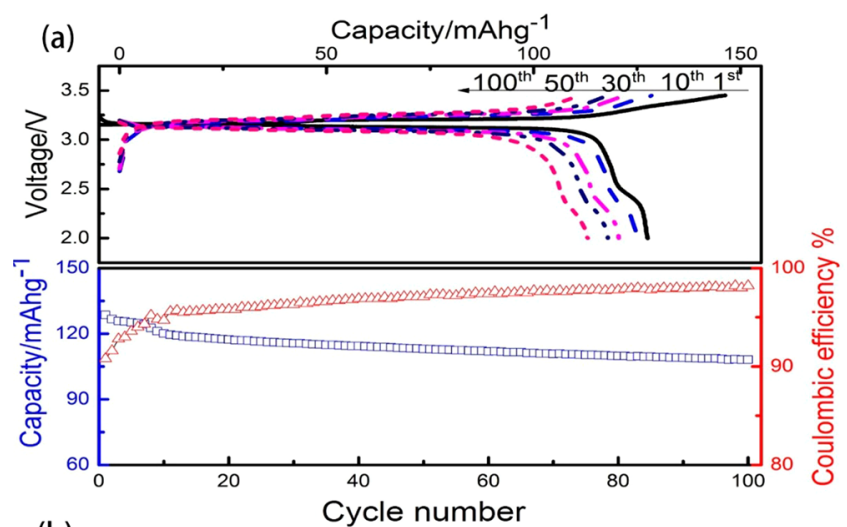

(b)

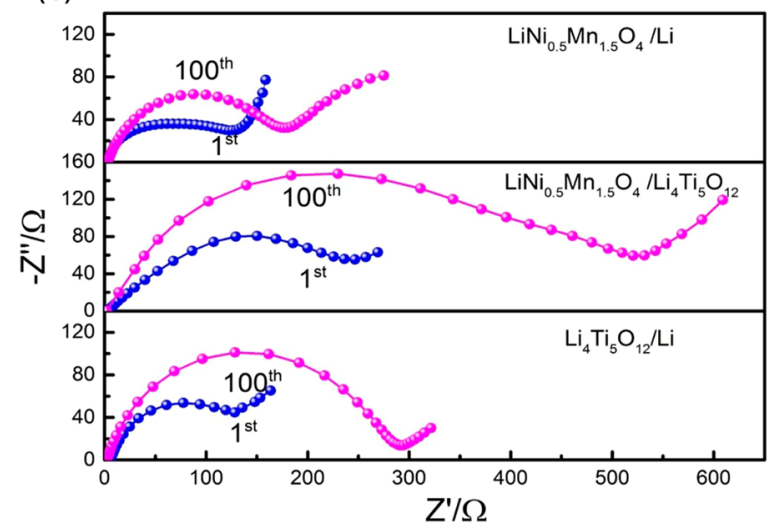

Figure 9. (a) Charge/discharge profiles, cycling performance, and Coulombic efficiency of $\mathrm{LiNi}_{0.5} \mathrm{Mn}_{1.5} \mathrm{O}_{4} / \mathrm{Li}_{4} \mathrm{Ti}_{5} \mathrm{O}_{12}$ cell with crosslinking PAMM; (b) EIS spectra of $\mathrm{LiNi}_{0.5} \mathrm{Mn}_{1.5} \mathrm{O}_{4} / \mathrm{Li}$ half-cell, $\mathrm{LiNi}_{0.5} \mathrm{Mn}_{1.5} \mathrm{O}_{4} / \mathrm{Li}_{4} \mathrm{Ti}_{5} \mathrm{O}_{12}$ full cell, and $\mathrm{Li}_{4} \mathrm{Ti}_{5} \mathrm{O}_{12} / \mathrm{Li}$ half-cell with PAMM.

inhabited efficiently because the induction of high voltageresisted gel network with anhydride group. When "shuangjian hebi” system containing anhydride and acrylate groups was applied, it polymerized at the surface of $\mathrm{LiNi}_{0.5} \mathrm{Mn}_{1.5} \mathrm{O}_{4}$ cathode and formed a stable, rigid cathode electrolyte interface owing to the $\mathrm{O}=\mathrm{C}-\mathrm{O}-\mathrm{M}(\mathrm{M}=\mathrm{Ni}, \mathrm{Mn})$ bonds. $^{50,51}$ The relevant evidence was displayed in Table S4, which showed the calculated coordination energy of $\mathrm{Mn}$ with other materials based on the density function theory. The favorable stable cathode interface could reduce the contact and reaction between carbonate electrolyte and cathode, and simultaneously suppress the dissolution of $\mathrm{Mn}^{2+}$ considerably, especially in harsh condition such as high voltage and high temperature. The schematic illustration was demonstrated in Figure 8 and depicted the morphology of CEI visually.

$\mathrm{LiNi}_{0.5} \mathrm{Mn}_{1.5} \mathrm{O}_{4} /$ Cross-Linking PAMM/Li $\mathrm{Ti}_{5} \mathrm{O}_{12}$ Full Cell Performances. The first $\mathrm{LiNi}_{0.5} \mathrm{Mn}_{1.5} \mathrm{O}_{4} / \mathrm{Li}_{4} \mathrm{Ti}_{5} \mathrm{O}_{12}$ full cell has already been shown in $2001 .{ }^{52}$ However, the cycling characteristic was still a debatable subject owing to the conventional electrolyte oxidation at the cathode at high working voltage vs $\mathrm{Li}^{+} / \mathrm{Li}$. Furthermore, the carbonate ingredient was liable to be catalytic decomposition at the existence of $\mathrm{Ti}^{4+}$, which would pose a threat on the performance and the safety of battery system. In our work, $\mathrm{LiNi}_{0.5} \mathrm{Mn}_{1.5} \mathrm{O}_{4} / \mathrm{Li}_{4} \mathrm{Ti}_{5} \mathrm{O}_{12}$ full cell was assembled to further evaluate the challenging feasibility and tolerance of cross-linking PAMM-based electrolyte, in which the electrode capacities were matched based on the mass of $\mathrm{Li}_{4} \mathrm{Ti}_{5} \mathrm{O}_{12}$. As presented in Figure 9a, the $\mathrm{LiNi}_{0.5} \mathrm{Mn}_{1.5} \mathrm{O}_{4} /$ $\mathrm{PAMM} / \mathrm{Li}_{4} \mathrm{Ti}_{5} \mathrm{O}_{12}$ showed excellent cycling stability due to the high ion conductivity and wide voltage window of PAMMbased electrolyte. The capacity of $128 \mathrm{mAh} \mathrm{g}^{-1}$ was delivered in the first cycle and $113.2 \mathrm{mAh} \mathrm{g}^{-1}$ remained with a Coulombic efficiency of $98.9 \%$ after 100 cycles, which was better than that of the full cell with commercial liquid electrolyte $\left(1 \mathrm{M} \mathrm{LiPF}_{6}\right.$ in EC-DEC) (Figure S10) as well as the previously reported battery system. ${ }^{53-55}$ In contrast, the cycling property of full cell with PAMM-based electrolyte at $55^{\circ} \mathrm{C}$ was measured and showed in Figure S11, which delivered a capacity of $91.8 \mathrm{mAh}$ $\mathrm{g}^{-1}$ after 23 cycles. The severe capacity fading may be ascribed to the aggravated catalytic decomposition of EC and DEC by $\mathrm{Ti}^{4+}$ at high temperature. From the rate performance measurement, the first cycle reversible capacity of $129 \mathrm{mAh}$ $\mathrm{g}^{-1}$ was delivered at $0.1 \mathrm{C}$ and $50 \mathrm{mAh} \mathrm{g}^{-1}$ was remained at $5 \mathrm{C}$ (Figure S12). Because the PAMM-based electrolyte had prominent interface stability with $\mathrm{LiNi}_{0.5} \mathrm{Mn}_{1.5} \mathrm{O}_{4}$ and $\mathrm{Li}$ metal as mentioned above, in order to investigate the fading reason for full cell, EIS spectra of $\mathrm{LiNi}_{0.5} \mathrm{Mn}_{1.5} \mathrm{O}_{4} / \mathrm{PAMM} / \mathrm{Li}$ half-cell, $\mathrm{LiNi}_{0.5} \mathrm{Mn}_{1.5} \mathrm{O}_{4} / \mathrm{PAMM} / \mathrm{Li}_{4} \mathrm{Ti}_{5} \mathrm{O}_{12}$ full cell and $\mathrm{Li}_{4} \mathrm{Ti}_{5} \mathrm{O}_{12} / \mathrm{PAMM} / \mathrm{Li}$ half-cell were shown in Figure $9 \mathrm{~b}$. Interfacial resistance for each cell increased with cycling and the $\mathrm{Li}_{4} \mathrm{Ti}_{5} \mathrm{O}_{12}$ half-cell displayed a much faster increase compared to that of the $\mathrm{LiNi}_{0.5} \mathrm{Mn}_{1.5} \mathrm{O}_{4}$ half cell. The interaction between $\mathrm{Li}_{4} \mathrm{Ti}_{5} \mathrm{O}_{12}$ and PAMM will be discussed in our further work to dilute the reason for faster increase resistance. It can be deduced that the interfacial impedance of anode side made a greater contribution to the impedance increase as well as the capacity fading of the full cell. It also elucidated the reason why the properties of $\mathrm{LiNi}_{0.5} \mathrm{Mn}_{1.5} \mathrm{O}_{4}$ halfcell were superior than that of the $\mathrm{LiNi}_{0.5} \mathrm{Mn}_{1.5} \mathrm{O}_{4} / \mathrm{Li}_{4} \mathrm{Ti}_{5} \mathrm{O}_{12}$ full cell.

\section{CONCLUSIONS}

In summary, we proposed a strategy to solve the challenges of $\mathrm{LiNi}_{0.5} \mathrm{Mn}_{1.5} \mathrm{O}_{4}$ high voltage battery system by in situ generated cross-linking poly(acrylic anhydride-2-methyl-acrylic acid-2oxirane-ethyl ester-methyl methacrylate) (PAMM) electrolyte inspired by "shuangjian hebi" concept. The cross-linking PAMM-based electrolyte not only integrated the advantages of both acrylic anhydride and methyl methacrylate, including high ion conductivity at room temperature $\left(6.79 \times 10^{-4} \mathrm{~S}\right.$ $\mathrm{cm}^{-1}$ ), broad voltage window (above $5 \mathrm{~V}$ ), stable interfacial compatibility with $\mathrm{Li}$ metal, but also overcome the shortcoming of low mechanical strength of PMMA. Furthermore, the in situ polymerization of two monomer solutions in battery formed excellent contact and superior binding between PAMM-based electrolyte and both electrodes. As a result, the $\mathrm{LiNi}_{0.5} \mathrm{Mn}_{1.5} \mathrm{O}_{4} /$ Li cell with PAMM-based electrolyte showed notably improved cycling stability, Coulombic efficiency, and rate capability at room temperature and $55{ }^{\circ} \mathrm{C}$ when compared with the battery used PMMA-based electrolyte. The EIS, ICP, and SEM results rationally demonstrated that the PAMM formed a more stable passivation layer on the cathode surface, which was ion conductive and effectively resistant to electrolyte decomposition and transition metal dissolution owing to the synergistic effects of anhydride and acrylate groups. The performance of $\mathrm{LiNi}_{0.5} \mathrm{Mn}_{1.5} \mathrm{O}_{4} / \mathrm{PAMM} / \mathrm{Li}_{4} \mathrm{Ti}_{5} \mathrm{O}_{12}$ full cell further proved the feasibility of PAMM-based electrolyte in high voltage battery system. A capacity of $128 \mathrm{mAh} \mathrm{g}^{-1}$ and a significantly improved Coulombic efficiency of $96 \%$ at $0.1 \mathrm{C}$ after 100 cycles for $\mathrm{LiNi}_{0.5} \mathrm{Mn}_{1.5} \mathrm{O}_{4} / \mathrm{Li}_{4} \mathrm{Ti}_{5} \mathrm{O}_{12}$ were first presented. Although further insight work is still in progress for elucidating the interfacial evolution, these findings demonstrated that the 
PAMM-based electrolyte was a very promising candidate toward the batteries with high working potential and even at high operational temperature.

\section{ASSOCIATED CONTENT}

\section{S Supporting Information}

The Supporting Information is available free of charge on the ACS Publications website at DOI: 10.1021/acsami.7b11342.

Physical properties of PAMM-based electrolyte, XPS test of surface chemical composition, test for the symmetric cells with PAMM-based electrolyte, chemical properties of PAMM-based electrolyte at $55{ }^{\circ} \mathrm{C}$ and in full cell (PDF)

\section{AUTHOR INFORMATION}

\section{Corresponding Author}

*E-mail: cuigl@qibebt.ac.cn.

ORCID

Guanglei Cui: 0000-0002-8008-7673

\section{Author Contributions}

All authors have given approval to the final version of the manuscript.

\section{Notes}

The authors declare no competing financial interest.

\section{ACKNOWLEDGMENTS}

We thank Qingdao Key Lab of Solar Energy Utilization and Energy Storage Technology, Qingdao Institute of Bioenergy and Bioprocess Technology, Chinese Academy of Sciences, Qingdao 266101, P. R. China, for fruitful help. This work is financially supported by the Strategic Priority Research Program of the Chinese Academy of Sciences (Grant XDA09010105), Think-Tank Mutual Fund of Qingdao Energy Storage Industry Scientific Research, "135” Projects Fund of CAS-QIBEBT Director Innovation Foundation, Qingdao Science and Technology Program (17-1-1-26-jch), and China Postdoctoral Science Foundation (2017M612366)

\section{REFERENCES}

(1) Goodenough, J. B.; Park, K.-S The Li-Ion Rechargeable Battery: A Perspective. J. Am. Chem. Soc. 2013, 135, 1167-1176.

(2) Bruce, P. G.; Scrosati, B.; Tarascon, J.-M. Nanomaterials for Rechargeable Lithium Batteries. Angew. Chem., Int. Ed. 2008, 47, 2930-2946.

(3) Ma, J.; Hu, P.; Cui, G. L.; Chen, L. Q. Surface and Interface Issues in Spinel $\mathrm{LiNi}_{0.5} \mathrm{Mn}_{1.5} \mathrm{O}_{4}$ : Insights into a Potential Cathode Material for High Energy Density Lithium Ion Batteries. Chem. Mater. 2016, 28, 3578-3606.

(4) Goodenough, J. B.; Kim, Y. Challenges for Rechargeable Batteries. J. Power Sources 2011, 196, 6688-6694.

(5) Boesenberg, U.; Falk, M.; Ryan, C. G.; Kirkham, R.; Menzel, M.; Janek, J.; Fröba, M.; Falkenberg, G.; Fittschen, U. E. Correlation Between Chemical and Morphological Heterogeneities in LiNi0.5Mn1.5O4 Spinel Composite Electrodes for Lithium-Ion Batteries Determined by Micro-X-ray Fluorescence Analysis. Chem. Mater. 2015, 27, 2525-2531.

(6) Hwang, T.; Lee, J. K.; Mun, J. Y.; Choi, W. C. Surface-Modified Carbon Nanotube Coating on High-Voltage $\mathrm{LiNi}_{0.5} \mathrm{Mn}_{1.5} \mathrm{O}_{4}$ Cathodes for Lithium Ion Batteries. J. Power Sources 2016, 322, 40-48.

(7) Porcarelli, L.; Gerbaldi, C.; Bella, F.; Nair, J. R. Super Soft AllEthylene Oxide Polymer Electrolyte for Safe All-Solid Lithium Batteries. Sci. Rep. 2016, 6, 19892.
(8) Kunduraci, M.; Al-Sharab, J. F.; Amatucci, G. G. High-Power Nanostructured $\mathrm{LiMn}_{2-\mathrm{x}} \mathrm{Ni}_{\mathrm{x}} \mathrm{O}_{4}$ High-Voltage Lithium-Ion Battery Electrode Materials: Electrochemical Impact of Electronic Conductivity and Morphology. Chem. Mater. 2006, 18, 3585-3592.

(9) Kim, J.-H.; Myung, S.-T.; Yoon, C. S.; Kang, S. G.; Sun, Y.-K. Comparative Study of $\mathrm{LiNi}_{0.5} \mathrm{Mn}_{1.5} \mathrm{O}_{4-\delta}$ and $\mathrm{LiNi}_{0.5} \mathrm{Mn}_{1.5} \mathrm{O}_{4}$ Cathodes Having Two Crystallographic Structures: $F d 3 \mathrm{~m}$ and $\mathrm{P}_{3} 32$. Chem. Mater. 2004, 16, 906-914.

(10) Sigala, C.; Le Gal La Salle, A.; Piffard, Y.; Guyomard, D. Influence of the $\mathrm{Cr}$ Content on the $\mathrm{Li}$ Desertion Behavior of the $\mathrm{LiCr}_{\mathrm{y}} \mathrm{Mn}_{2-\mathrm{y}} \mathrm{O}_{4}(0 \leq y \leq 1)$ Compounds: I. Separation of Bulk and Superficial Processes at High Voltage. J. Electrochem. Soc. 2001, 148, A812-A818.

(11) Zhang, H.; Fu, L.; Wu, Y.; Wu, H. Changes of $\mathrm{LiCoO}_{2}$ Cathode Material for Lithium-Ion Battery during Long Cycling Electrochem. Electrochem. Solid-State Lett. 2007, 10, A283-A285.

(12) Kim, H.; Nguyen, D.; Bae, H.; Lee, J.; Cho, B. W.; Kim, H.; Cheong, M.; Lee, H. Effect of Ether Group on the Electrochemical Stability of Zwitterionic Imidazolium Compounds. Electrochem. Commun. 2008, 10, 1761-1764.

(13) Chai, J.; Zhang, J.; Hu, P.; Ma, J.; Du, H.; Yue, L.; Zhao, J.; Wen, H.; Liu, Z.; Cui, G.; Chen, L. A High-Voltage Poly (methylethyl $\alpha$ cyanoacrylate) Composite Polymer Electrolyte for $5 \mathrm{~V}$ Lithium Batteries. J. Mater. Chem. A 2016, 4, 5191-5197.

(14) Park, S.-R.; Jung, Y.-C.; Shin, W.-K.; Ahn, K. H.; Lee, C. H.; Kim, D.-W. Cross-linked Fibrous Composite Separator for High Performance Lithium-ion Batteries with Enhanced Safety. J. Membr. Sci. 2017, 527, 129-136.

(15) Chen, T.; Liao, Y.; Wang, X.; Luo, X.; Li, X.; Li, W. Investigation on High-Safety Lithium Ion Battery Using Polyethylene Supported Poly(methyl methacrylate-acrylonitrile-butyl acrylate) Copolymer Based Gel Electrolyte. Electrochim. Acta 2016, 191, 923-932.

(16) Hu, P.; Chai, J.; Duan, Y.; Liu, Z.; Cui, G.; Chen, L. Progress in Nitrile-Based Polymer Electrolytes for High Performance Lithium Batteries. J. Mater. Chem. A 2016, 4, 10070-10083.

(17) Liu, Z.; Hu, P.; Ma, J.; Qin, B.; Zhang, Z.; Mou, C.; Yao, Y.; Cui, G. Conformal Poly(ethyl $\alpha$-cyanoacrylate) Nano-Coating For Improving the Interface Stability of $\mathrm{LiNi}_{0.5} \mathrm{Mn}_{1.5} \mathrm{O}_{4}$. Electrochim. Acta 2017, 236, 221-227.

(18) Liu, Z.; Chai, J.; Xu, G.; Wang, Q.; Cui, G. Functional Lithium Borate Salts and Their Potential Application in High Performance Lithium Batteries. Coord. Chem. Rev. 2015, 292, 56-73.

(19) Luo, X.; Liao, Y.; Xie, H.; Zhu, Y.; Huang, Q.; Li, W. Enhancement of Cyclic Stability for High Voltage Lithium Ion Battery at Elevated Temperature by Using Polyethylene-Supported Poly(methylmethacrylate-butyl acrylate- acrylonitrile- styrene). Electrochim. Acta 2016, 220, 47-56.

(20) Yan, G.; Li, X.; Wang, Z.; Guo, H.; Xiong, X. Beneficial Effects of 1-propylphosphonic Acid Cyclic Anhydride as an Electrolyte Additive on the Electrochemical Properties of $\mathrm{LiNi}_{0.5} \mathrm{Mn}_{1.5} \mathrm{O}_{4}$ Cathode Material. J. Power Sources 2014, 263, 231-238.

(21) Bouayad, H.; Wang, Z.; Dupré, N.; Dedryvère, R.; Foix, D.; Franger, S.; Martin, J.-F.; Boutafa, L.; Patoux, S.; Gonbeau, D.; Guyomard, D. Improvement of Electrode/Electrolyte Interfaces in High-Voltage Spinel Lithium-Ion Batteries by Using Glutaric Anhydride as Electrolyte Additive. J. Phys. Chem. C 2014, 118, 4634-4648.

(22) Tarnopolskiy, V.; Kalhoff, J.; Nadherna, M.; Bresser, D.; Picard, L.; Fabre, F.; Rey, M.; Passerini, S. Beneficial Influence of Succinic Anhydride as Electrolyte Additive on the Self-discharge of $5 \mathrm{~V}$ $\mathrm{LiNi}_{0.4} \mathrm{Mn}_{1.6} \mathrm{O}_{4}$ Cathodes. J. Power Sources 2013, 236, 39-46.

(23) Peng, S.; Cao, Q.; Yang, J.; Zou, X.; Jing, B.; Dai, W. A Novel Electrospun Poly(vinylidene fluoride)/thermoplastic polyurethane/ poly(vinylidene fluoride)-g-(maleic anhydride) Porous Fibrous Polymer Electrolyte for Lithium-ion Batteries. Solid State Ionics 2015, 282, $49-53$.

(24) Lijima, T.; Toyoguchi, Y.; Eda, N. Quasi-solid organic electrolytes gelatinized with polymethyl-methacrylate and their applications for lithium batteries. Denki Kagaku 1985, 53, 619-623. 
(25) Flora, X.; Ulaganathan, M.; Rajendran, S. Influence of Lithium Salt Concentration on PAN-PMMA Blend Polymer Electrolytes. Int. J. Electrochem. Sci. 2012, 7, 7451-7462.

(26) Amine, K. ATD Program Review Meeting, Berkeley, CA, Nov $3-$ 5, 1999.

(27) Song, J.; Wang, Y.; Wan, C. Review of Gel-type Polymer Electrolytes for Lithium-ion Batteries. J. Power Sources 1999, 77, 183197.

(28) Nair, J. R.; Destro, M.; Gerbaldi, C.; Bongiovanni, R.; Penazzi, N. Novel Multiphase Electrode/Electrolyte Composites for Next Generation of Flexible Polymeric Li-Ion Cells. J. Appl. Electrochem. 2013, 43, 137-145.

(29) Gerbaldi, C.; Destro, M.; Nair, J. R.; Ferrari, S.; Quinzeni, I.; Quartarone, E. High-rate V2O5-Based Li-Ion Thin Film Polymer Cell with Outstanding Long-Term Cyclability. Nano Energy 2013, 2, 12791286.

(30) Pan, Z. Polymer Chemistry, 5th ed; Chemical Industry Press: Beijing, 2011.

(31) Cui, Y.; Liang, X.; Chai, J.; Cui, Z.; Wang, Q.; He, W.; Liu, X.; Liu, Z.; Cui, G.; Feng, J. High Performance Solid Polymer Electrolytes for Rechargeable Batteries: A Self-Catalyzed Strategy toward Facile Synthesis. Adv. Sci. 2017, 1700174.

(32) Zhou, D.; He, Y.; Cai, Q.; Qin, X.; Li, B.; Du, H.; Yang, Q.; Kang, F. Investigation of Cyano Resin-Based Gel Polymer Electrolyte: In Situ Gelation Mechanism and Electrode-Electrolyte Interfacial Fabrication in Lithium-Ion Battery. J. Mater. Chem. A 2014, 2, 2005920066.

(33) Okamoto, Y. Ab Initio Calculations of Thermal Decomposition Mechanism of LiPF6-Based Electrolytes for Lithium-Ion Batteries. J. Electrochem. Soc. 2013, 160, A404-A409.

(34) Gao, K.; Hu, X.; Yi, T.; Dai, C. PE-g-MMA Polymer Electrolyte Membrane for Lithium Polymer Battery. Electrochim. Acta 2006, 52, 443-449.

(35) Zhang, J.; Zhao, J.; Yue, L.; Wang, Q.; Chai, J.; Liu, Z.; Zhou, X.; Li, H.; Guo, Y.; Cui, G.; Chen, L. Safety-Reinforced Poly(Propylene Carbonate)-Based All-Solid-State Polymer Electrolyte for AmbientTemperature Solid Polymer Lithium Batteries. Adv. Energy Mater. 2015, 5, 1501082.

(36) Yang, L.-Y.; Wei, D.-X.; Xu, M.; Yao, Y.-F.; Chen, Q. Transferring Lithium Ions in Nanochannels: A PEO/ $\mathrm{Li}^{+}$Solid Polymer Electrolyte Design. Angew. Chem., Int. Ed. 2014, 53, 36313635.

(37) Daigle, J.-C.; Vijh, A.; Hovington, P.; Gagnon, C.; HamelPaquet, J.; Verreault, S.; Turcotte, Na.; Clement, D.; Guerfi, A.; Zaghib, K. Lithium Battery with Solid Polymer Electrolyte Based on Comb-Like Copolymers. J. Power Sources 2015, 279, 372-383.

(38) Ma, Y.; Li, L.; Gao, G.; Yang, X.; You, Y. Effect of Montmorillonite on the Ionic Conductivity and Electrochemical Properties of a Composite Solid Polymer Electrolyte Based on Polyvinylidenedifluoride/Polyvinyl Alcohol Matrix for Lithium Ion Batteries. Electrochim. Acta 2016, 187, 535-542.

(39) Jin, L.; Howlett, P.; Pringle, J.; Janikowski, J.; Armand, M.; MacFarlane, D. R.; Forsyth, M. An Organic Ionic Plastic Crystal Electrolyte for Rate Capability and Stability of Ambient Temperature Lithium Batteries. Energy Environ. Sci. 2014, 7, 3352-3361.

(40) Ortiz, G.; Cabello, M.; Lopez, M.; Tirado, J.; Mcdonald, M.; Yang, Y. Exploring a Li-ion Battery Using Surface Modified Titania Nanotubes Versus High Voltage Cathode Nanowires. J. Power Sources 2016, 303, 194-202.

(41) Demeaux, J.; Caillon-Caravanier, M.; Galiano, H.; Lemordant, D.; Claude-Montigny, B. $\mathrm{LiNi}_{0.4} \mathrm{Mn}_{1.6} \mathrm{O}_{4}$ /Electrolyte and Carbon Black/Electrolyte High Voltage Interfaces: To Evidence the Chemical and Electronic Contributions of the Solvent on the CathodeElectrolyte Interface Formation. J. Electrochem. Soc. 2012, 159, A1880-A1890.

(42) Metzger, M.; Marino, C.; Sicklinger, J.; Haering, D.; Gasteiger, $\mathrm{H}$. Anodic Oxidation of Conductive Carbon and Ethylene Carbonate in High-Voltage Li-Ion Batteries Quantified by On-Line Electro- chemical Mass Spectrometry. J. Electrochem. Soc. 2015, 162, A1123A1134.

(43) Von Cresce, A.; Xu, K. Electrolyte Additive in Support of $5 \mathrm{~V} \mathrm{Li}$ Ion Chemistry. J. Electrochem. Soc. 2011, 158, A337-A342.

(44) Lu, D.; Yuan, L.; Li, J.; Huang, R.; Guo, J.; Cai, Y. Failure Mechanism for High Voltage Graphite/ $\mathrm{LiNi}_{0.5} \mathrm{Mn}_{1.5} \mathrm{O}_{4}$ (LNMO) Liion Cells Stored at Elevated Temperature. J. Electroanal. Chem. 2015, $758,33-38$.

(45) Wang, J.; Yamada, Y.; Sodeyama, K.; Chiang, C.; Tateyama, Y.; Yamada, A. Superconcentrated Electrolytes for A High-voltage Lithium-ion Battery. Nat. Commun. 2016, 7, 12032.

(46) Sushko, P.; Rosso, K.; Zhang, J.-G.; Liu, J.; Sushko, M. Oxygen Vacancies and Ordering of d-levels Control Voltage Suppression in Oxide Cathodes: the Case of Spinel $\mathrm{LiNi}_{0.5} \mathrm{Mn}_{1.5} \mathrm{O}_{4-\delta}$. Adv. Funct. Mater. 2013, 23, 5530.

(47) Zuo, X. X.; Fan, C. J.; Xiao, X.; Liu, J. S.; Nan, J. M. HighVoltage Performance of $\mathrm{LiCoO}_{2} /$ Graphite Batteries with Methylene Methanedisulfonate as Electrolyte Additive. J. Power Sources 2012, 219, 94-99.

(48) Andersson, A. M.; Abraham, D. P.; Haasch, R.; MacLaren, S.; Liu, J.; Amine, K. Surface Characterization of Electrodes from High Power Lithium-Ion Batteries. J. Electrochem. Soc. 2002, 149, A1358.

(49) Tang, Y. X.; Deng, J. Y.; Li, W. L.; Malyi, O. I.; Zhang, Y. Y.; Zhou, X. R.; Pan, S. W.; Wei, J. Q.; Cai, Y. R.; Chen, Z.; Chen, X. D. Water-Soluble Sericin Protein Enabling Stable Solid-Electrolyte Interphase for Fast Charging High Voltage Battery Electrode. Adv. Mater. 2017, 29, 1701828.

(50) Verma, P.; Maire, P.; Novák, P. A. Review of the Features and Analyses of the Solid Electrolyte Interphase in Li-ion Batteries. Electrochim. Acta 2010, 55, 6332-6341.

(51) Yan, G. C.; Li, X. H.; Wang, Z. X.; Guo, H. J.; Xiong, X. H. Beneficical Effects of 1-Propylphosphonic Acid Cyclic Anhydride as an Electrolyte Additive on the Electrochemical Properties of Li$\mathrm{Ni}_{0.5} \mathrm{Mn}_{1.5} \mathrm{O}_{4}$ Cathode Material. J. Power Sources 2014, 263, 231-238.

(52) Ariyoshi, K.; Iwakoshi, Y.; Nakayama, N.; Ohzuku, T. Topotactic Two-Phase Reactions of $\mathrm{Li}\left[\mathrm{Ni}_{1 / 2} \mathrm{Mn}_{3 / 2}\right] \mathrm{O}_{4}\left(\mathrm{P}_{3} 32\right)$ in Nonaqueous Lithium Cells. J. Electrochem. Soc. 2004, 151, A296A303.

(53) Liu, G.; Wen, L.; Liu, G. Y.; Luo, H.; Ma, B.; Wu, Q.; Tian, Y. Synthesis and Electrochemical Properties of $\mathrm{LiNi}_{0.4} \mathrm{Mn}_{1.5} \mathrm{Cr}_{0.1} \mathrm{O}_{4}$ and $\mathrm{Li}_{4} \mathrm{Ti}_{5} \mathrm{O}_{12}$. Met. Mater. Int. 2011, 17, 661-664.

(54) Kim, J.-H.; Pieczonka, N. P. W.; Sun, Y.-K.; Powell, B. R. Improved Lithium-Ion Battery Performance of $\mathrm{LiNi}_{0.5} \mathrm{Mn}_{1.5-\mathrm{x}} \mathrm{Ti}_{\mathrm{x}} \mathrm{O}_{4}$ High Voltage Spinel in Full-Cells Paired with Graphite and $\mathrm{Li}_{4} \mathrm{Ti}_{5} \mathrm{O}_{12}$ Negative Electrodes. J. Power Sources 2014, 262, 62-71.

(55) Zhang, Z.; Hu, L.; Wu, H.; Weng, W.; Koh, M.; Redfern, P. C.; Curtiss, L. A.; Amine, K. Fluorinated Electrolytes for 5 V Lithium-ion Battery Chemistry. Energy Environ. Sci. 2013, 6, 1806-1810. 